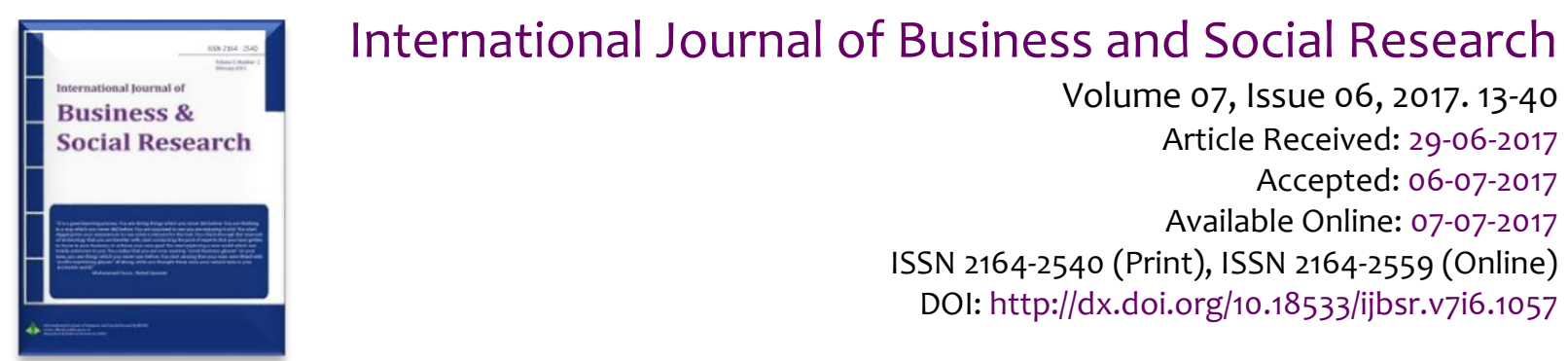

\title{
Trends in Innovation Activities in Manufacturing Industries across Development Echelons
}

\begin{abstract}
Abdullah M. Khan'
ABSTRACT

This empirical paper explores trends in innovation activities measured by a countries' total patent application submission intensity relative to its population, and by analyzing U.S. granted patents data for cohorts of developed countries and developing countries. In addition to tabular and graphical analyses, I use a baseline regression model and a variant model thereof to assess the relative influence of a set of aggregate variables on innovation activities in eight manufacturing industries across two cohorts of countries (developed and developing) where each cohort contains eight individual countries. Eight industries included in this study are: Chemical, Petroleum, electrical and electronics equipment, machinery, pharmaceutical, plastic, computer, and textile. The cohort of developed countries includes Australia, Canada, Czech Republic, France, Italy, Poland, Switzerland, and the United States. The cohort of developing countries includes Brazil, China, India, Malaysia, Mexico, Russia, South Africa, and Turkey. Per regression results, ethnic diversity is a statistically significant positive determinant of innovation for all industry aggregate patent count for both high income and developing countries. Also, per capita electricity usage, $R \& D$ expenditure as percent of GDP, and percent of population with internet access are three positive factors of innovation irrespective of industrial subsectors and position of a country in the development echelon. Interestingly, impact of ICT-services export is statistically significant and innovation boosting in developing countries in the cohort relative to countries in the cohort of developed countries. It also appears that trade openness served as a stronger stimulant of innovation activities for developing countries' but not as much for the cohort of developed or high-income countries. This paper attempts to extend the literature on cross-country comparison of innovation activities by using two measures of innovation activities across developed and developing countries, and by analyzing both aggregate and sector-level data for eight manufacturing industries both graphically and utilizing panel regression models.
\end{abstract}

Keywords: Innovation, manufacturing industries, patent applications, patent count.

JEL Codes: Lo, O3, F4.

This is an open access article under Creative Commons Attribution 4.0 License, 2017.

\section{Introduction}

Innovation across industrial sectors is one of the major catalysts for sustainable economic growth (d'Agostino and Scarlato, 2015; Morck and Yeung, 2001; OECD, 2007; ŞTefan, and Coca, 2015; Wu, 2010).

\footnotetext{
${ }^{1}$ Assistant Professor of Economics, School of Business Administration, Claflin University. E-mail: akhan@claflin.edu
} 
Researchers from several public and private think tanks and intergovernmental economic agencies continue to emphasize on bolstering innovation activities to boost national competitiveness in global marketplace ${ }^{2}$. The study of innovation in the manufacturing industries gained fresh momentum in the backdrop of recent decline in manufacturing industries' employment and increase in merchandize trade deficit in developed economies. Several studies (e.g., Diez and Gopinath, 2014; Cohen and Zysman, 1988) expressed concern about manufacturing industries' global competitiveness for those national economies. Loss of employment in manufacturing industries and increase in merchandize trade deficit both rose across most of the developed countries in the recent years. For example, according to U.S. Census Bureau's database, between 1986 and 2015 U.S. manufacturing industry's employment shrunk from 19.1 million to 11.6 million.

According to a Canadian governmental statistical agency report, between 2000 and 2007 Canada lost about 17 percent jobs in the manufacturing industries. The same report mentions manufacturing industry's loss of employment in other industrialized countries. Between 1990 and 2003 manufacturing sector's employment decreased by 29 percent in the United Kingdom. According to an OECD database, between 1990 and 2016, merchandize trade deficit increased from US\$-101.72 billion to US\$-736.80 billion (an increase of 624 percent) for the United States and from US\$-39.8 billion to US\$-179.69 billion (an increase of 352 percent) for United Kingdom.

For developing countries study of innovation in the manufacturing industries is important for several reasons such as maintenance or increase in global market share of merchandize export, appearance as attractive off-shore location to prospective foreign direct investors from developed countries, and, in persuasion of policies aimed at import substitution, export promotion or deficit reduction. Naude, Szirmai and Goedhuys (2011) articulated the importance of leveraging innovation-entrepreneurship nexus for economic development of developing countries. Using an objective of innovation and source of innovation framework, an OECD report (2012) contends positive role of innovation in promoting economic growth and development across countries currently at each development echelon.

This study aims to contribute to existing literature in a few ways. I analyze the impact of some macroeconomic determinants on patented innovation activities both at manufacturing industry level and at sectoral level. I analyze the impact of a set of determinants on innovative activities in manufacturing industry and on eight sectors thereof. The eight manufacturing sectors included in this study are chemical, petroleum, electrical equipment, machinery, pharmaceutical, plastic, computer, and textile. The benefit of sub-sectoral analysis over aggregate analysis is that it yields more reliable results as sectoral data usually contain less noise than aggregate data (Ulku, 2007). Another contribution of this paper is analysis of determinants of innovative activities using multiple measures. In this study, I use two different measures of innovative activities: per capita patent granted by U.S. and by number of patent application submitted per ten thousand of population of the concerned countries. I compare the data using two cohorts: developing and developed countries as categorized by the World Bank according to individual countries' per capita Gross National Income status.

The remaining sections of the paper are organized as follows: Section 2 contains a review of literature, section 3 describes data and variables, section 4 summarizes the regression results and some other empirical analysis, section 5 mentions of some policy implications based on the empirical findings and some limitations of the study, and section 6 concludes the paper.

\section{Literature review}

Innovative activities are knowledge and technology intensive activities and are well documented in literature as major catalysts of productivity growth and economic development (Audretsch and

\footnotetext{
2 For example, please see the Council on competitiveness report by Deloitte, 2016; council of competitiveness report of 2005 , U.S. National Economic Council and Office of Science and technology policy report, 2015; the OECD report on innovation and growth, 2007.
} 
Feldman,1996; Grossman and Helpman, 1993; Jaffe, Trajtenberg, and Henderson, 1993; Rosenberg, 2004; Solow, 1956 and 1957). Schumpeter (1942) described innovation to be a process of 'creative destruction' which enables introduction of new products and processes, and thus makes 'old' products and processes obsolete. Romer's contributions $(1986,1992,1990)$ in the endogenous growth theory inspired a fresh wave of studies of macroeconomic determinants of economic growth using data from time horizon which marked a shift from prior macroeconomic research trend which mainly was focused on studying of shorter time horizon business cycles (Sala-i-Martin, 2002). As research on macroeconomic determinants of economic growth gained momentum, studies on innovation also started to focus on macroeconomic climates in addition to firm-level microeconomic factors. Valuing this holistic approach in innovation research, terms such as 'innovation ecosystem' is gaining popularity in the concerned circles as a growing strand of innovation literature (Engel, 2015; Jackson, 2011; Frenkel and Maital, 2014; Gooble, 2014).

Ulku (2007) analyzes data of four manufacturing industries from seventeen OECD countries and reports that knowledge stock is the main determinant of innovation. Bluestone and Clayton-Matthews (2013) report role of innovation in life sciences as catalyst of economic growth across four sectors of manufacturing industries: chemicals, drugs and medicine, electrical and electronics, and machinery and transport. Gorodnichenko, Yuriy, Svejnar, and Terrell (2008) studied data from twenty-seven emerging market economies and found statistical evidence supporting a negative effect of competitive market structure on innovation especially for firms located further from the frontier. Onodera (2008) found statistical evidence of positive impact of trade on innovation activities. Love and Roper (1999) studied 1300 U.S. manufacturing plants' data and found statistical evidence that the R\&D, technology transfer and networking are to some extent substitutes as determinants of innovation activities. Subrahmanya (2011) used Indian Small and Medium Enterprises (SMEs) level data for 157 firms over five-year period in his analysis and found that presence of dedicated product design office and entrepreneurs with technical background were among the most significant determinants of innovation. Lee (2004) studies determinants of innovation using firm level data of Malaysian manufacturing industries and found that firm size is a positive determinant of innovation in Malaysian manufacturing industries. Almeida and Fernandes (2007) uses firm level data from forty-three developing countries and find international trade to be the most significant catalyst of technological innovation in these countries.

Economists often refer to globalization as a process of international integration in commodity, capital, and, labor markets (Bordo et al, 2003). I contend that major driving forces in the current wave of globalization are advances in ICTs, and, trade liberalization. This new era of globalization since 1990s has been reinforced by the mass use of the Internet, and due to enactment of multilateral free trade agreements among various bilateral and multilateral stakeholders resulting in decrease in various tariff and non-tariff barriers 3 .

There is a growing body of literature studying emerging market countries' economic growth and innovation activities (e.g., Neill, 2007; Khan and Roy, 2011; Chen and De Lombaerde, 2014). However, there is a dearth of literature in data-intensive analyses of sectoral performance which allows the current paper to contribute in this regard. Literature strand that measures contribution of Information and Communication Technologies (ICTs) on economic growth and development is also growing rapidly (Morck and Yeung, 2001; Colecchia and Schreyer, 2002; Jalava and Pohjola, 2002). ICTs made distance communication faster and cheaper, and has revolutionized supply chain management over long distances cost effectively. Export of ICT-goods and service are also fetching export revenues for incumbent countries. Among the emerging economies, India recently achieved a commendable market share in ICT-services (NASSCOM, 2011). Countries around the world are trying to leverage ICTs for cost savings and export revenue maximization purposes.

\footnotetext{
3 Examples of such trade agreements are North American Free Trade Agreement (NAFTA), Southern Common Market (MERCOSUR), ASEAN Free Trade Area (AFTA), Central European Free Trade Agreement (CEFTA), South Asian Free Trade Agreement, Treaty establishing the Common Market for Eastern and Southern Africa (COMESA), various trade agreements signed by Caribbean Community (CARICOM) secretariat etc.
} 


\section{Data and methodology}

I have selected eight 'developed' countries from the high-income country group list, and eight 'developed' countries from upper middle income and lower middle-income country group lists of the World Bank. The eight high income countries included in the study are Australia, Canada, Czech Republic, France, Italy, Switzerland, Poland, and United States ${ }^{4}$. The developing countries included in this study are Brazil, India, China, Malaysia, Mexico, Russia, South Africa, and, Turkey ${ }^{5}$ I I accessed the patent count data for these countries from U.S. Patent and Trade Organization database. These patents are issued by the United States Patent and Trademark Office (USPTO.). A benefit of using patent data as a measure of innovation activities is that it provides as with an alternative measure of rate of technical progress (Ulku, 2007). The USPTO patent data was obtained in aggregate of all sector and for seven manufacturing sectors for the period since 1990 to 2008. The patent application data was obtained from OECD database for the period 1960 to 2015. The macroeconomic, fiscal, and other control variables are retrieved from the World Bank databases. We estimate the impact of determinants on innovation using the following baseline and globalization model econometric specifications. The baseline model is as follows:

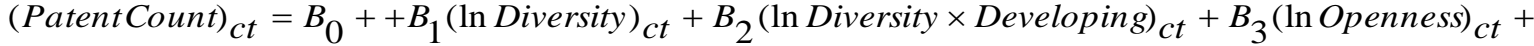

$$
\begin{aligned}
& B_{4}(\ln \text { Openness } \times \text { Developing })_{c t}+B_{5}(\ln \text { Electricity })_{c t}+B_{6}(\ln \text { Electricity } \times \text { Developing })_{c t}+B_{7}(\ln R \& D)_{c t} \\
& +B_{8}(\ln R \& D \times \text { Developing })_{c t}+B_{9}(\ln \text { TertiaryEd })_{c t}+B_{10}(\ln \text { TertiaryEd } \times \text { Developing })_{c t}+B_{11}(C I T)_{c t}+ \\
& B_{12}(C I T \times \text { Developing })_{c t}+B_{13}(P I T)_{c t}+B_{14}(C I T \times \text { Developing })_{c t}+\varepsilon_{c t}
\end{aligned}
$$

All variables are measured at their natural log. The subscript ' $c$ ' stands for sixteen individual countries and subscript ' $t$ ' stands for years 1990 to 2008. The variable 'Diversity' is calculated as an inverse ratio of the percent of the largest ethnic group to the percent of the rest of the people in the country ${ }^{6}$.For example, if the largest ethnic groups in country A and country B are 60 percent and 75 percent respectively, then their diversity indices will be 0.67 and 0.33 respectively, and, in that case country $A$ will be taken as more ethnically diverse than country $B$. The data about ethnic diversity is obtained from the CIA World Factbook database. The variable Openness is the ratio of foreign trade to GDP7. Some strand of empirical literature finds trade openness as a promoter of new ideas and innovations (e.g., Kirimaya, 2012) and, as a positive influence on innovation measured by granted patents (e.g., Khan and Roy, 2011). However, some other scholars (e.g., Onodera, 2008) report ambiguous impact of international trade on innovation and mentions that sometimes trade can impact innovation adversely due to its negative effect of import on domestic producers. When import gets cheaper due to free trade, domestic producers may not be able to achieve scale economies which may also result in decrease in rent available to fund domestic $R \& D$ and innovation activities. I contend trade openness as a positive factor of innovation.

The variable R\&D is calculated as R\&D expenditure as a percent of GDP. The variable 'Tertiary Education' implies enrollment in post-secondary education as a percent of all enrollment. All these variables are expected to display positive correlation with innovation. The variables R\&D expenditure as share of GDP and tertiary education are constructed per data obtained from the World Bank database. The data on corporate income tax (CIT) and personal income tax (PIT) revenues as percent of GDP was collected from IMF database. The dummy variable 'Developing' assumes a value of 1 for the eight developing countries and assumes a value of zero if otherwise. The $\varepsilon$ represents stochastic error term.

\footnotetext{
4 The terms 'developed countries' and 'high income countries' may sometimes be used interchangeably in the literature including this paper.

5 The terms 'developing countries' and 'emerging countries' may sometimes be used interchangeably in the literature including this paper.

6 i.e., Diversity is equal to percent sum of all other minorities divided by percent of largest ethnic group. Diversity increases as this ratio increases.
}

7 i.e., Openness $=\left(\frac{\text { Value of import }+ \text { Value of export })}{G D P}\right)$. 
I expect to see statistically significant positive correlation between ethnic diversity and innovation activities as reported in recent literature (Nathan and Lee, 2013; Ozgen, Nijkamp, and Poot, 2011; Ostergaard, and Timmermans, 2011; Parrotta, Pozzoli, and Pytlikova, 2014). I expect the sign of the estimated coefficient for ICT-goods and ICT-service exports to be positive per existing empirical literature (e.g., Falk, 2004). I use the ratio of ICT-exports to all exports as proxies for ICT-intensity measures of a country and contend that more ICT-intensive a country is, more patented innovation that country will be able to accomplish. I expect the estimated coefficient for the tariff rate variable to be negative implying that higher import tariff restricts overall volume of foreign trade due to retaliatory measures of trading partner countries and as a result protectionist behavior cripple's innovation activities. The globalization model I include some additional variables to measure influence of technology and trade liberation, and thus the specification now takes the following form:

$(\text { PatentCount })_{c t}=B_{0}+B_{1}(\ln \text { Internet })_{c t}+B_{2}(\ln \text { Internet } \times \text { Developing })_{c t}+B_{3}(\ln \text { Diversity })_{c t}$ $+B_{4}(\ln \text { Diversity } \times \text { Developing })_{c t}+B_{5}(\ln \text { Openness })_{c t}+B_{6}(\ln \text { Openness } \times \text { Developing })_{c t}+B_{7}(\ln \text { Electricity })_{c t}$ $+B_{8}(\ln \text { Electricity } \times \text { Developing })_{c t}+B_{9}(\ln R \& D)_{c t}+B_{10}\left(\ln R \& D \times\right.$ Developing $_{c t}+B_{11}(\ln \text { TertiaryEd })_{c t}$ $+B_{12}(\ln \text { TertiaryEd } \times \text { Developing })_{c t}+B_{13}(C I T)_{c t}+B_{14}(C I T \times \text { Developing })_{c t}+B_{15}(P I T)_{c t}+$ $B_{16}(\text { CIT } \times \text { Developing })_{c t}+B_{17}(\text { ICTgoodsExport })_{c t}+B_{18}(\text { ICTgoodsExport } \times \text { Developing })_{c t}+$ $B_{19}(\text { ICTservice Export })_{c t}+B_{20}(\text { ICT serviceExp ort } \times \text { Developing })_{c t}+B_{21}($ Tariff $) c t+B_{22}($ Developing $)+\varepsilon_{c t}$ In the globalization model above, all variables are normalized by using their natural log values for the regressions. The variable Internet implies percent of people with Internet access. The variable Electricity implies per capita consumption of electricity. The subscript $c$ stands for the sixteen countries (the eight developed or high-income countries and the eight developing countries), and the subscript $t$ stands for the years from 1990 to 2008. Each specification has three variant models: one for random effect, another for fixed effect and the other is heteroskedasticity robust generalized least square (GLS) model.

I incorporate four variables in the globalization model. The variable 'ICT-goods export as share of all goods export' is showing percent of all goods export-revenue that has been earned by respective countries in respective years by exporting ICT goods. Similarly, variable 'ICT-services export as share of all services export' is showing percent of revenue from all services export that was earned by exporting ICT-goods. Data for these variables were taken from the World Bank database. The data for trade weighted average tariff rate was retrieved from the World Bank database. I was particularly curious regarding the signs and magnitudes of the estimated coefficients of these four variables that I use to measure direction and magnitude of globalization forces on innovation activities. I am interested in the coefficients related to the diversity variable and the developing country interaction variables. I expect the coefficients of these interaction variables to convey important information regarding the difference in the relative effectiveness of these variables to influence patented innovation activities in the developing versus developed (i.e., high income) countries. I estimate total nine sets of regressions among which one set has aggregate patent count for all industries as the dependent variable, and the remaining eight sets have respective eight manufacturing industries' patent counts as dependent variables. Each set contains baseline model and globalization model specifications.

Our baseline regression specification is that of a fixed effect model. As noted earlier, I also analyze random effect and generalized least square model to control for heteroskedasticity and multicollinearity. Regression results of the fixed effect model are of interest under the assumption that there are some factors within each individual country that may impact or bias the predictor or outcome variables and we need to control for these. The random effect model regression results will be relevant under the assumption that the variations across countries are random and uncorrelated with the predictor or independent variables included in the $\operatorname{model}^{8}$. I use the generalized least squared method to cure for

\footnotetext{
${ }^{8}$ According to Green (2008) the main distinction between fixed effect and random effect is whether the unobserved individual effect entails elements that are correlated with the regressors in the model, not whether these effects are stochastic or not.
} 
heteroskedasticity and multicollinearity as some diagnostic tests suggested the presence of these problems in the model specification.

Figure $1 \mathrm{~A}$

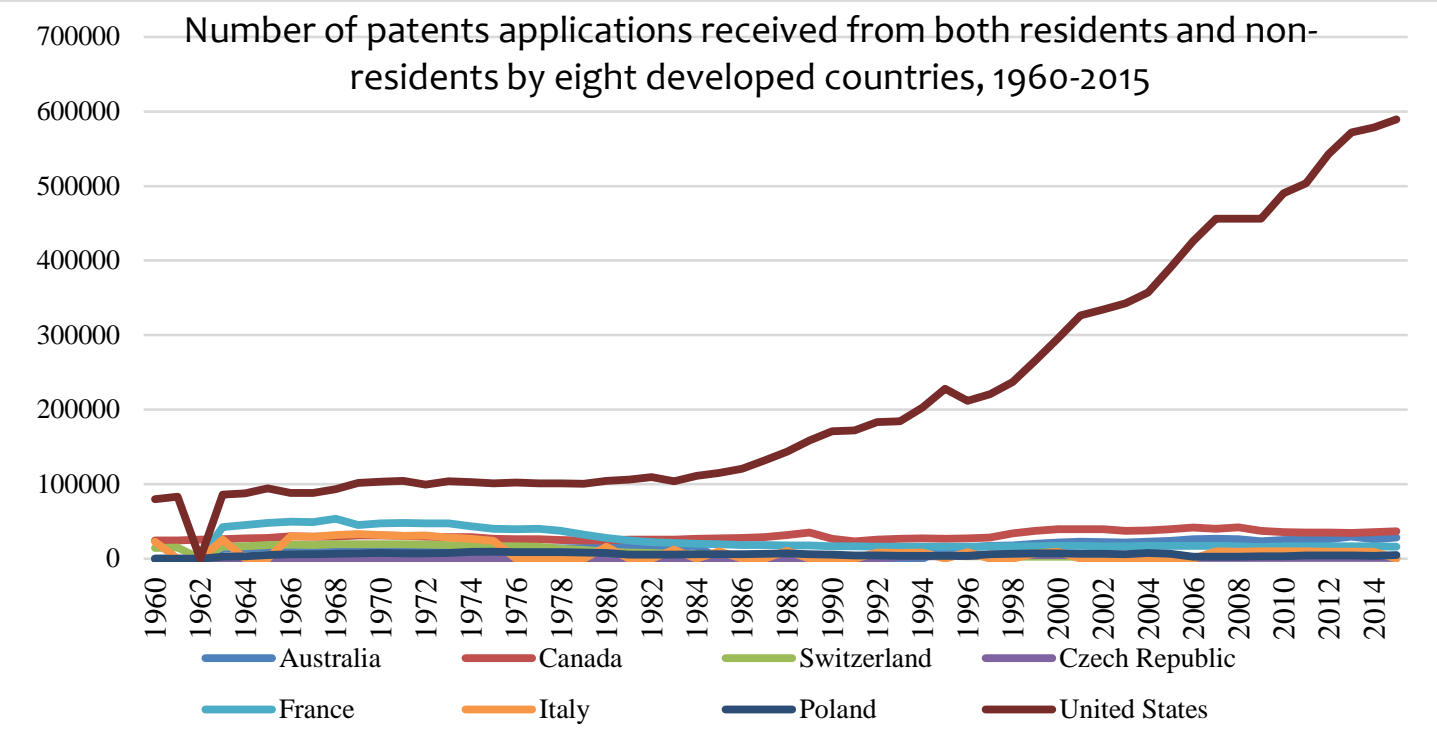

Source: Figure created by author using the World Bank online database

Figure 1B

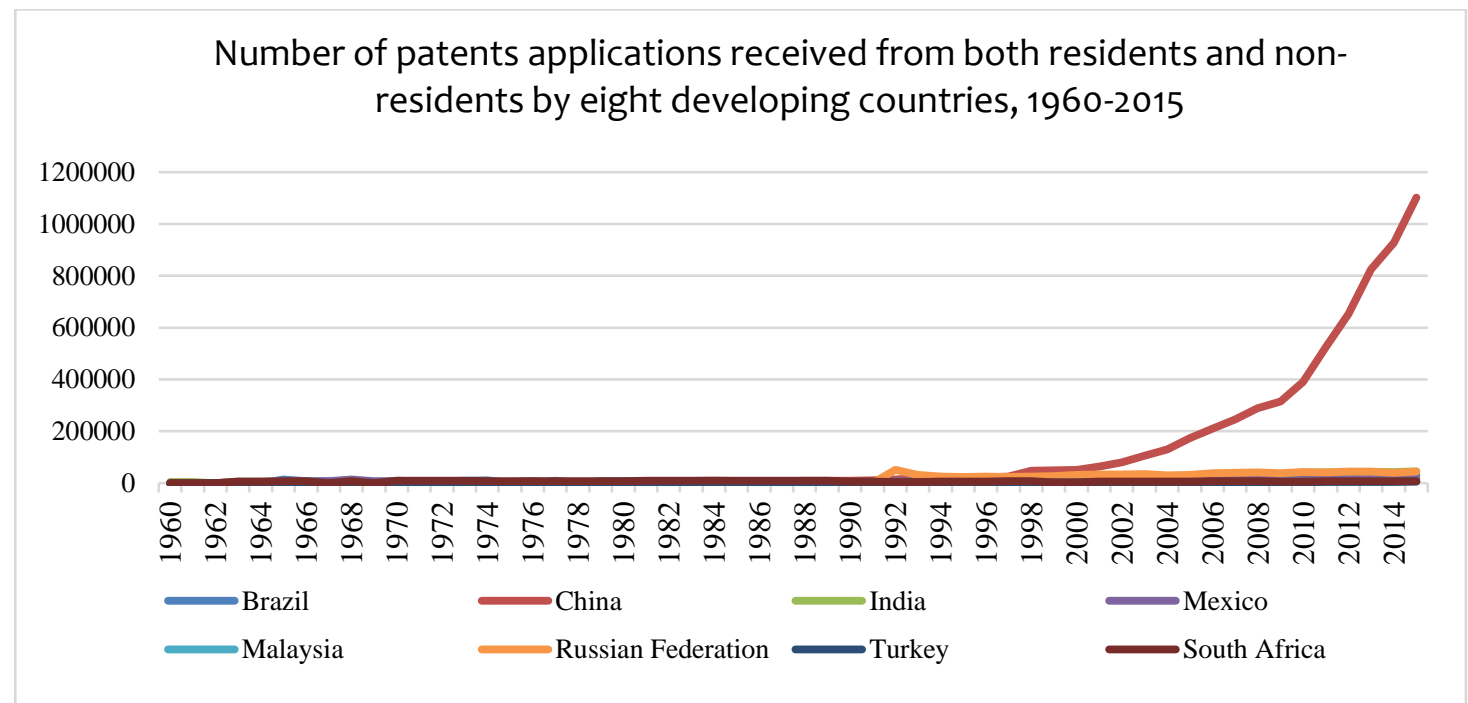

Source: Figure created by author using the World Bank online database

Figure $1 \mathrm{~A}$ through Figure $1 \mathrm{~F}$ illustrate trends in patents for eight manufacturing industries' patent application activities for fifty-six years from 1960 through 2015. Figure $1 \mathrm{~A}$ and Figure $1 \mathrm{~B}$ depict total patent application submission trends for cohort of developed and developing countries respectively. The Figures show that USA from the developed country cohort and China from the developing country cohort are leading the way in terms of receipt of patent application. 
Figure $1 C$

Patent applications per ten thousand inhabitants: Eight developed countries

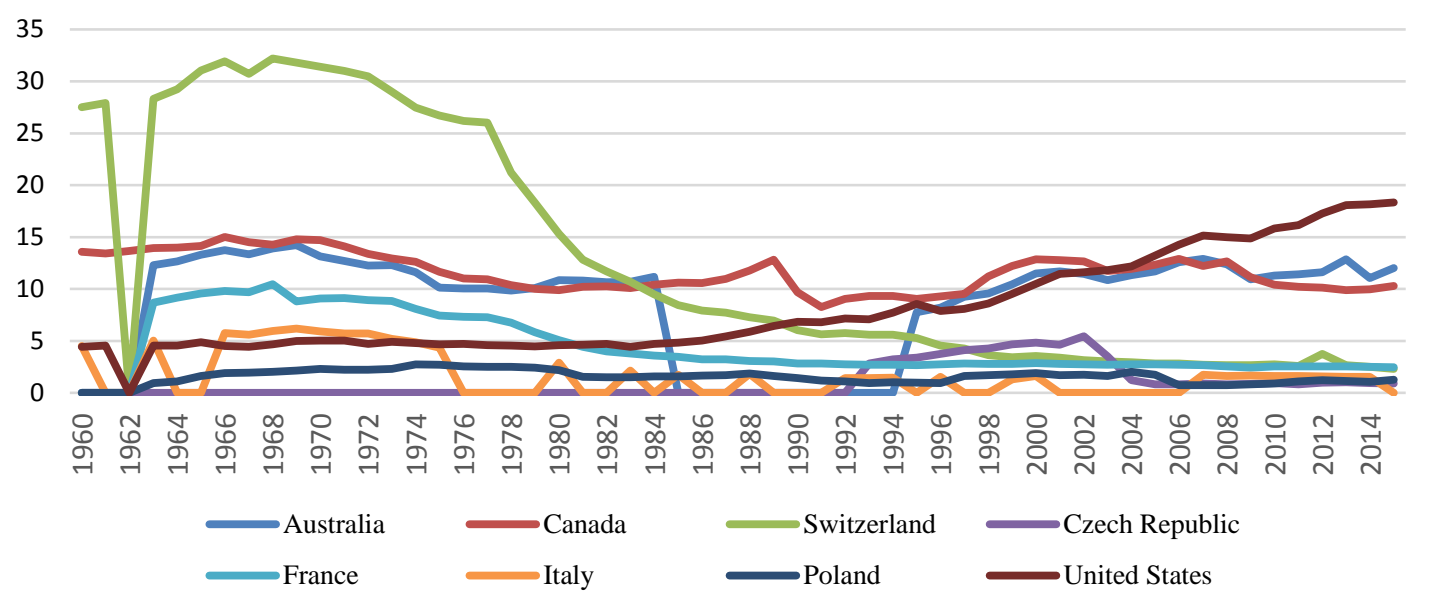

Source: Figure created by author using the World Bank online database

Figure 1D

Patent applications per ten thousand inhabitants: Eight developing countries

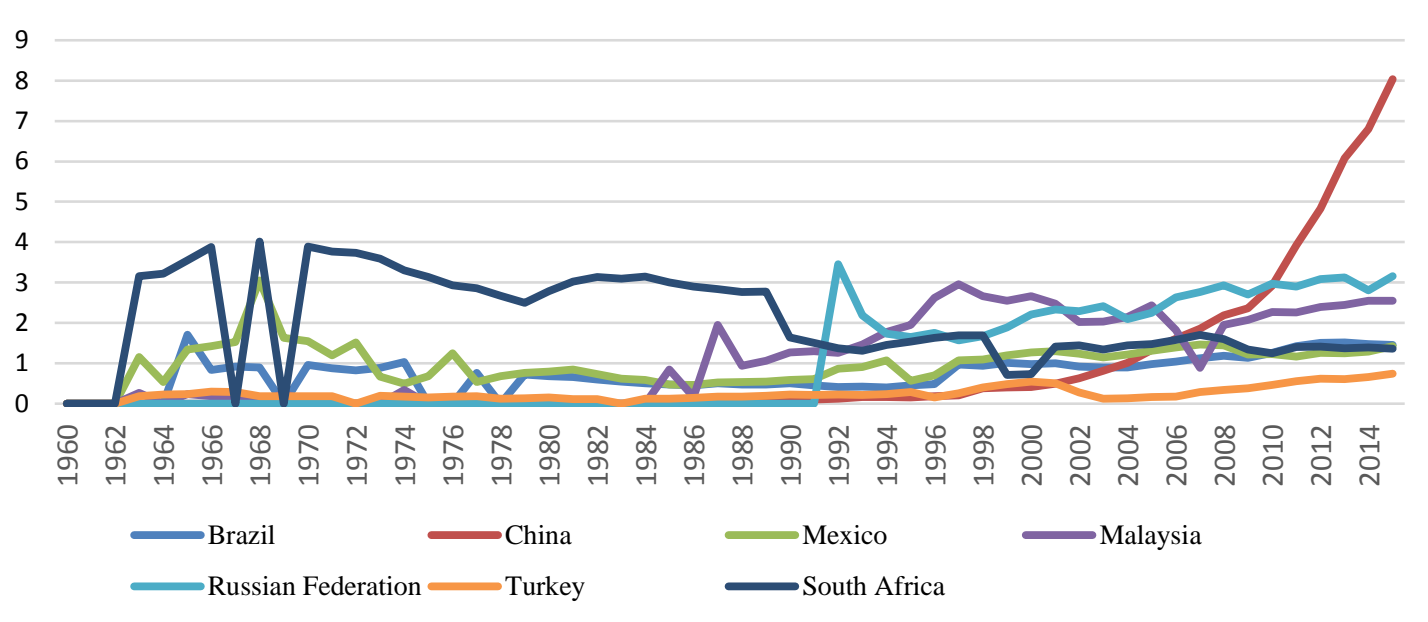

Source: Figure created by author using the World Bank online database

In Figure $1 C$ and Figure $1 \mathrm{D}$ we present that same patent application data for the same eight countries but this time I express the data per ten thousand people?.

As seen in Figure $1 C$ throughout 1960 s and 1970s Switzerland experienced higher patent application per ten thousand residents, and then it the application dropped over successive years. USA is experiencing spike in number of application received per 10K residents since the beginning of 1990 .

As Figure 1D shows, despite China's population density, the patent application per 10K residents is growing steeply since 2006.

\footnotetext{
9 For example, if Country A has received 100 patents applications in year 2015 when country A's population was 10,000, I express this data as 1 patent application per 10,000 people (i.e., 100 divided by 10,000).
} 
Figure 1E

Number of patents applications received from non-residents by eight developed countries, 1960-2015

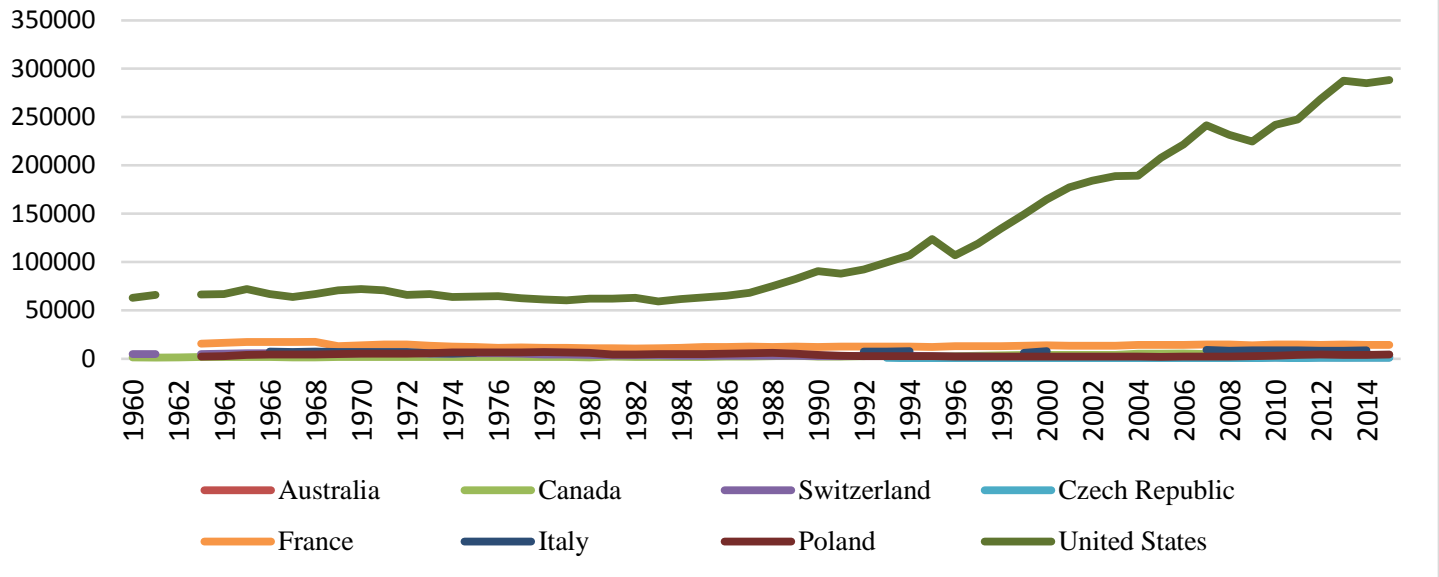

Source: Figure created by author using the World Bank online database

Figure $1 \mathrm{~F}$

Number of patents applications received from non-residents by eight developing countries, 1960-2015

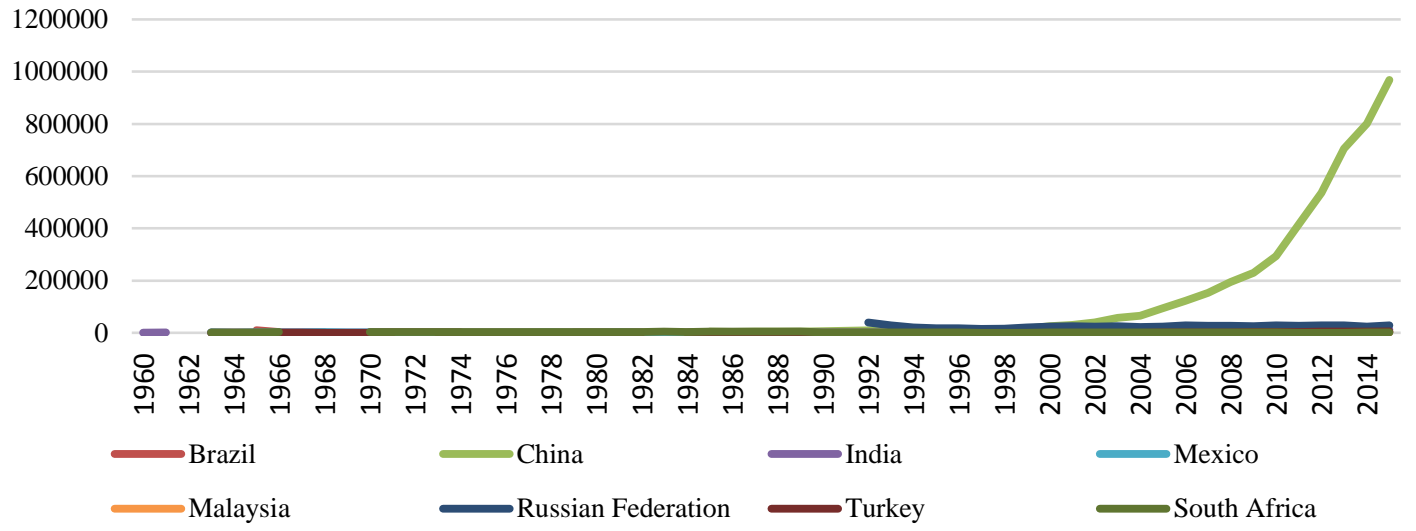

Source: Figure created by author using the World Bank online database

Figure $1 \mathrm{E}$ and Figure $1 \mathrm{~F}$ show that patent application received from non-residents are sharply increasing for both USA and China when other countries in these two cohorts are not experiencing any exciting growth in this regard. Table 1 present's percent share of the eight high income countries' U.S. issued patents and percent share of U.S. issued patents to the eight developing countries. It appears from Table 1 that U.S. issued patents share for high income cohort is either rising or remaining about the same whereas patent share of developing countries has fallen from about 20 percent in 1990 to about 10 percent in 2008.

Table 1: Total U.S. granted patent count in eight developed countries and eight developing countries in the study cohort relative to all U.S. granted patents, 1990-2018

\begin{tabular}{lrrrrr}
\hline Year & & $\begin{array}{r}\text { Patent Count } \\
\text { Developed } \\
\text { Countries }\end{array}$ & $\begin{array}{r}\text { Eight } \\
\text { Developing } \\
\text { countries }\end{array}$ & $\begin{array}{r}\text { Eight High } \\
\text { Income } \\
\text { Countries }\end{array}$ & $\begin{array}{r}\text { Eight } \\
\text { Developing } \\
\text { Countries }\end{array}$ \\
\hline 1990 & World & 48,683 & 177 & $53.87 \%$ & $0.20 \%$ \\
1991 & 90,365 & 190 & $54.42 \%$ & $20 \%$ \\
1992 & 96,511 & 52,518 & 71 & $54.86 \%$ & $7.3 \%$ \\
\hline
\end{tabular}




\begin{tabular}{lrrrrr}
\hline 1993 & 98,342 & 54,366 & 79 & $55.28 \%$ & $8.0 \%$ \\
1994 & 101,676 & 57,285 & 64 & $56.34 \%$ & $6.3 \%$ \\
1995 & 101,419 & 56,911 & 20 & $56.12 \%$ & $2.0 \%$ \\
1996 & 109,645 & 62,349 & 29 & $56.86 \%$ & $2.6 \%$ \\
1997 & 111,984 & 62,933 & 21 & $56.20 \%$ & $1.9 \%$ \\
1998 & 147,517 & 81,785 & 31 & $55.44 \%$ & $2.1 \%$ \\
1999 & 153,485 & 85,395 & 35 & $55.64 \%$ & $2.3 \%$ \\
2000 & 157,494 & 86,600 & 47 & 54.995 & $3.0 \%$ \\
2001 & 166,035 & 89,275 & 41 & $53.77 \%$ & $2.5 \%$ \\
2002 & 167,331 & 88,559 & 60 & $52.92 \%$ & $3.6 \%$ \\
2003 & 169,023 & 89,437 & 54 & $52.91 \%$ & $3.2 \%$ \\
2004 & 164,290 & 85,741 & 83 & $52.19 \%$ & $5.1 \%$ \\
2005 & 143,806 & 75,811 & 93 & $52.72 \%$ & $6.5 \%$ \\
2006 & 173,772 & 91,229 & 117 & $52.50 \%$ & $6.7 \%$ \\
2007 & 157,282 & 80,786 & 165 & $51.36 \%$ & $10.5 \%$ \\
2008 & 157,772 & 78,838 & 154 & $49.97 \%$ & $9.8 \%$ \\
\hline
\end{tabular}

Source: Authors' creation using data from the U.S. Patent and Trademark Office database. The eight developing countries are Brazil, China, India, Malaysia, Mexico, Russia, South Africa, and Turkey. The eight developed countries are: Australia, Canada, Czech Republic, France, Italy, Poland, Switzerland, and United States.

Figure $2 \mathrm{~A}$

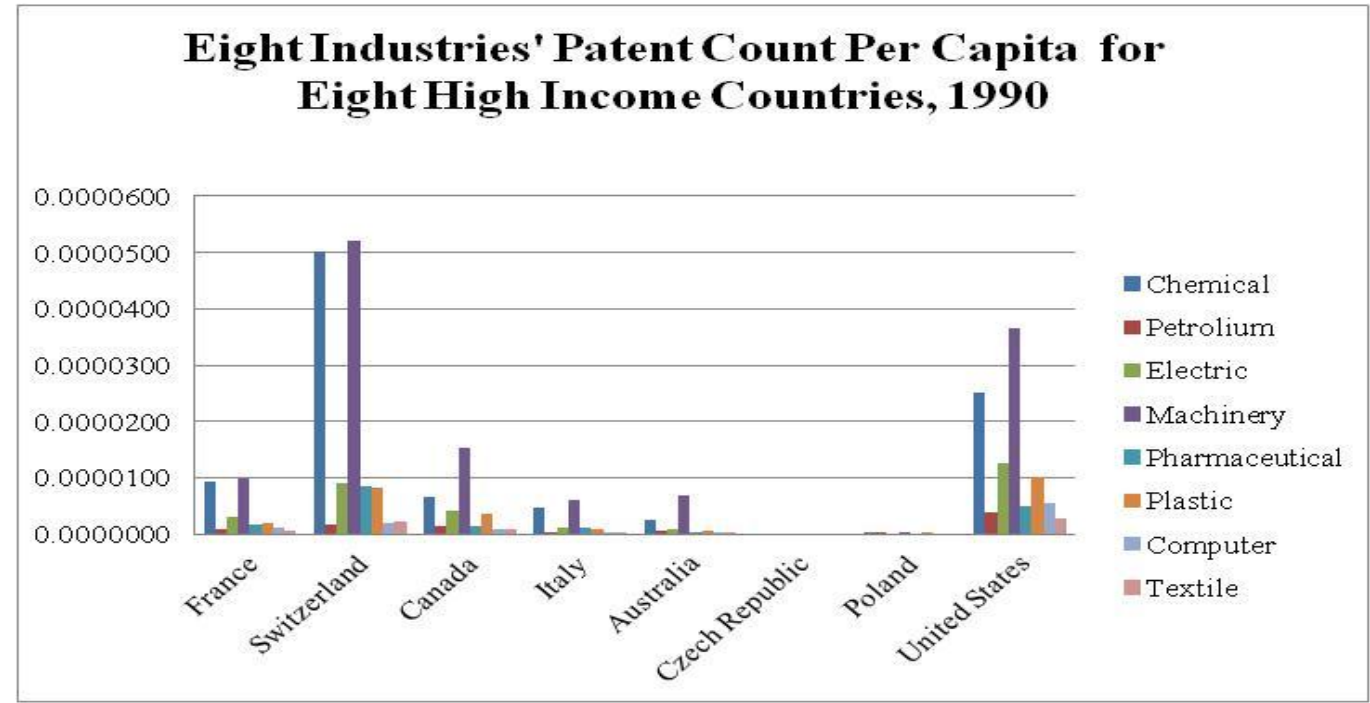

Source: Figure created by author using the USPTO database

Figure $2 \mathrm{~B}$

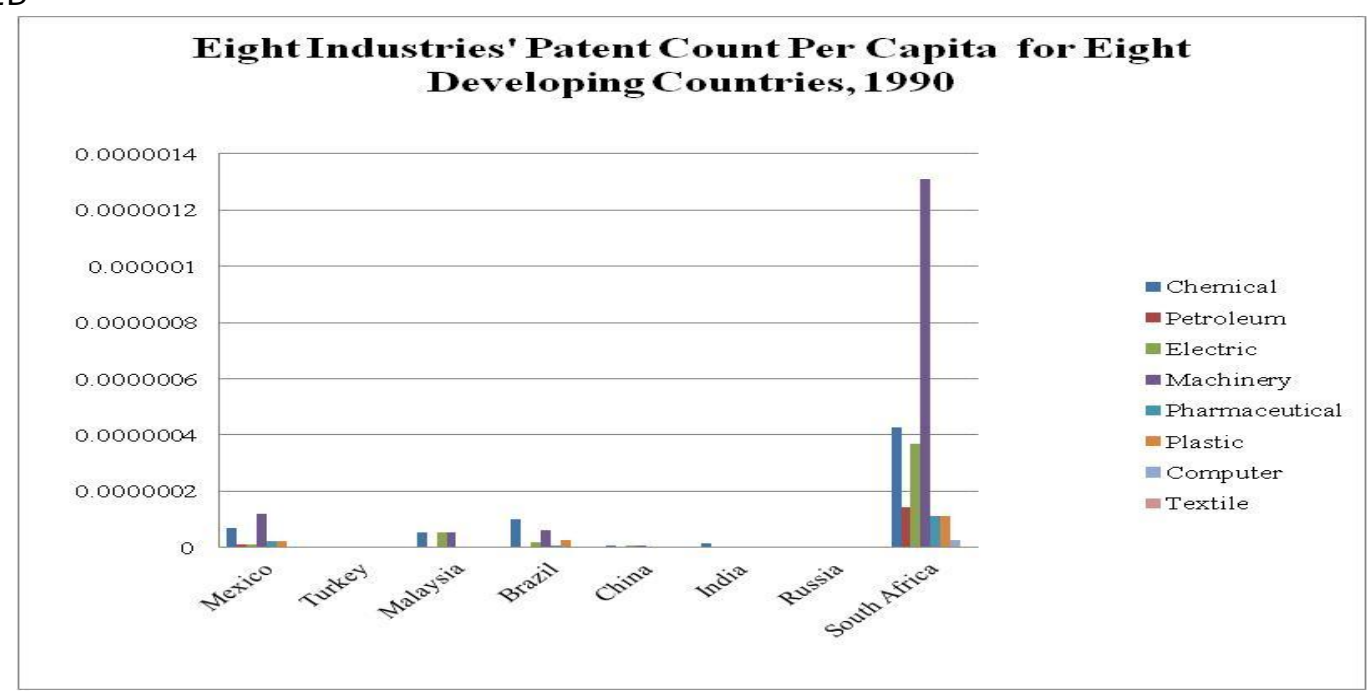

Source: Figure created by author using the USPTO database 
Figures $2 \mathrm{~A}$ and $2 \mathrm{~B}$ present per capita granted patent for two country-cohorts for eight manufacturing sectors for the year 1990. Switzerland and USA had highest number of patents per capita from the developed country cohort and South Africa had higher patents per capita relative to other seven countries in the developing country cohort. Figures 1 and 2 in the appendix section presenting the per capita patent count for the same two country-cohorts and same eight manufacturing industries for the year 2008. In Figure 3B we see that Malaysia and China achieved visible growth relative to other member countries in the number of patents granted per capita in 2008.

Figure $3 \mathrm{~A}$

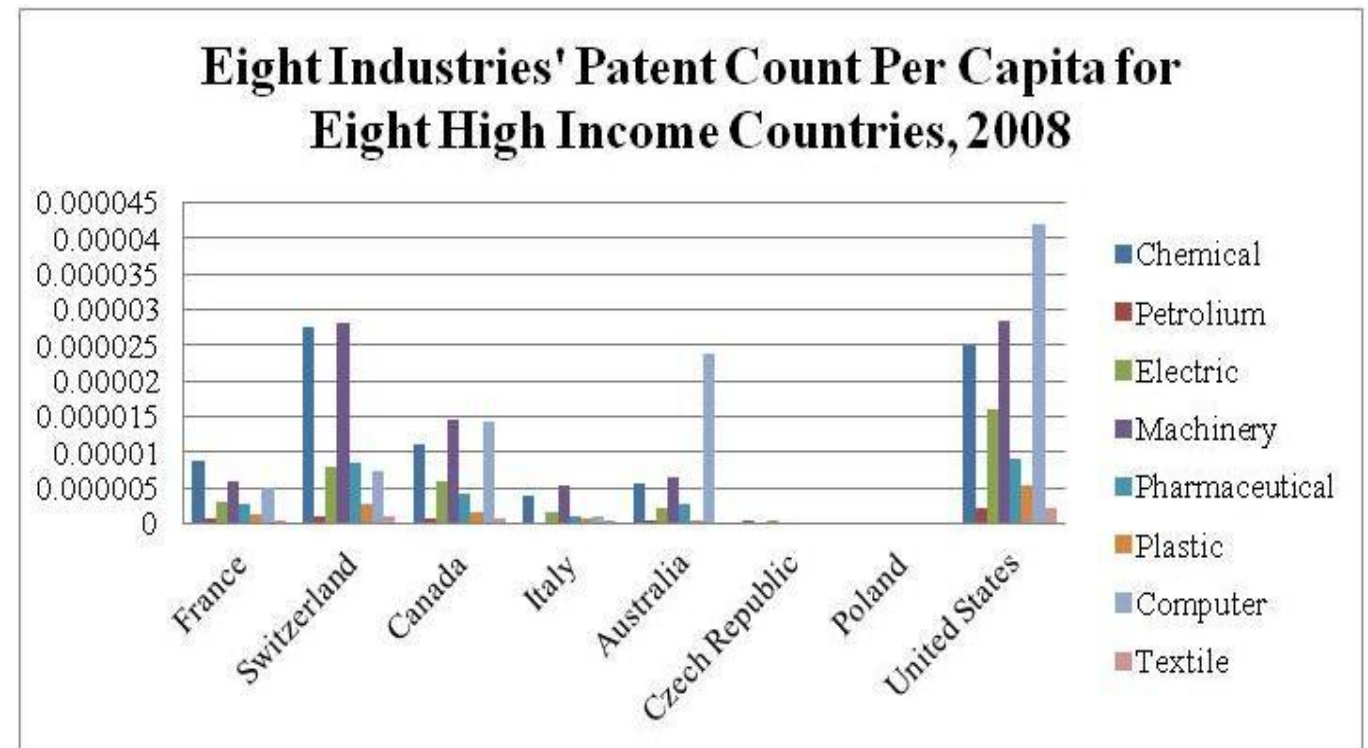

Source: Figure created by author using the USPTO database

Figure 3B

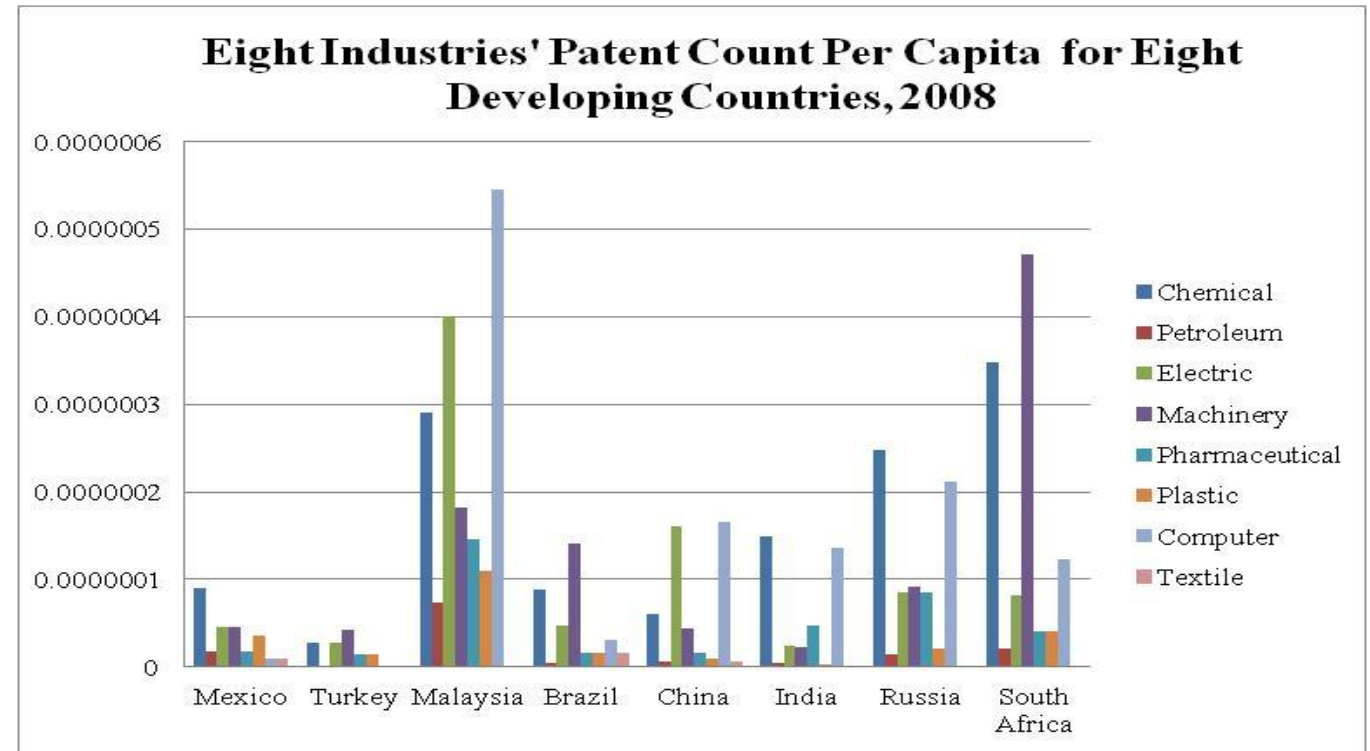

Source: Figure created by author using the USPTO database

Table 2: Eight industry U.S. granted patent count for eight high income countries and eight developing countries

\begin{tabular}{|c|c|c|c|c|c|c|c|c|c|c|}
\hline $\begin{array}{l}\text { Eight High } \\
\text { Income } \\
\text { Countries }\end{array}$ & Year & $\begin{array}{r}\text { All } \\
\text { Patent }\end{array}$ & Chemical & Petroleum & Electric & Machinery & $\begin{array}{l}\text { Pharma } \\
\text { ceutical }\end{array}$ & Plastic & Computer & Textile \\
\hline France & 1990 & 2,866 & 537 & 55 & 177 & 571 & 105 & 123 & 65 & 28 \\
\hline & 2008 & 3,163 & 575 & 54 & 187 & 388 & 175 & 86 & 316 & 19 \\
\hline Switzerland & 1990 & 1,284 & 337 & 11 & 60 & 349 & 58 & 56 & 14 & 15 \\
\hline
\end{tabular}




\begin{tabular}{lcrrrrrrrrr}
\hline \multirow{3}{*}{ Canada } & 2008 & 1,112 & 211 & 8 & 61 & 216 & 66 & 20 & 57 & 7 \\
& 1990 & 1,859 & 184 & 39 & 117 & 426 & 36 & 98 & 23 & 25 \\
Italy & 2008 & 3,393 & 369 & 26 & 198 & 491 & 136 & 55 & 476 & 22 \\
& 1990 & 1,259 & 267 & 17 & 68 & 344 & 61 & 56 & 14 & 15 \\
Australia & 2008 & 1,357 & 229 & 13 & 102 & 313 & 69 & 37 & 65 & 22 \\
& 2090 & 432 & 41 & 10 & 17 & 118 & 8 & 12 & 2 & 2 \\
Czech & 1990 & 1,291 & 120 & 8 & 44 & 137 & 58 & 11 & 512 & 4 \\
Republic & 2008 & 48 & 6 & 0 & 0 & 0 & 0 & 0 & 0 & 0 \\
\multirow{3}{*}{ Poland } & 1990 & 17 & 5 & 1 & 6 & 3 & 2 & 2 & 3 & 1 \\
United & 2008 & 54 & 4 & 1 & 1 & 10 & 1 & 1 & 0 & 0 \\
States & 1990 & 47,391 & 6,273 & 1,002 & 3,174 & 9,135 & 1,207 & 2,532 & 1,345 & 711 \\
& 2008 & 77,502 & 7,568 & 678 & 4,895 & 8,646 & 2,724 & 1,589 & 12,730 & 660 \\
\hline
\end{tabular}

\begin{tabular}{|c|c|c|c|c|c|c|c|c|c|c|}
\hline $\begin{array}{l}\text { Eight } \\
\text { Developing } \\
\text { Countries }\end{array}$ & Year & $\begin{array}{r}\text { All } \\
\text { Patent }\end{array}$ & Chemical & Petroleum & Electric & Machinery & $\begin{array}{l}\text { Pharma } \\
\text { ceutical }\end{array}$ & Plastic & Computer & Textile \\
\hline \multirow{2}{*}{ Mexico } & 1990 & 32 & 6 & 1 & 1 & 10 & 2 & 2 & 0 & 0 \\
\hline & 2008 & 54 & 10 & 2 & 5 & 5 & 2 & 4 & 1 & 1 \\
\hline \multirow[t]{2}{*}{ Turkey } & 1990 & 2 & 0 & 0 & 0 & 0 & 0 & 0 & 0 & 0 \\
\hline & 2008 & 16 & 2 & 0 & 2 & 3 & 1 & 1 & 0 & 0 \\
\hline \multirow{2}{*}{ Malaysia } & 1990 & 3 & 1 & 0 & 1 & 1 & 0 & 0 & 0 & 0 \\
\hline & 2008 & 152 & 8 & 2 & 11 & 5 & 4 & 3 & 15 & 0 \\
\hline \multirow{2}{*}{ Brazil } & 1990 & 41 & 15 & 0 & 3 & 9 & 1 & 4 & 0 & 0 \\
\hline & 2008 & 101 & 17 & 1 & 9 & 27 & 3 & 3 & 6 & 3 \\
\hline \multirow{2}{*}{ China } & 1990 & 47 & 8 & 0 & 6 & 9 & 1 & 0 & 2 & 3 \\
\hline & 2008 & 1,225 & 79 & 7 & 213 & 58 & 22 & 13 & 219 & 8 \\
\hline \multirow[t]{2}{*}{ India } & 1990 & 23 & 14 & 0 & 0 & 1 & 1 & 2 & 0 & 0 \\
\hline & 2008 & 634 & 170 & 5 & 28 & 25 & 54 & 3 & 155 & 0 \\
\hline \multirow{2}{*}{ Russia } & 1990 & 0 & 0 & 0 & 0 & 0 & 0 & 0 & 0 & 0 \\
\hline & 2008 & 176 & 35 & 2 & 12 & 13 & 12 & 3 & 30 & 0 \\
\hline South & 1990 & 114 & 15 & 5 & 13 & 46 & 4 & 4 & 1 & 0 \\
\hline Africa & 2008 & 91 & 17 & 1 & 4 & 23 & 2 & 2 & 6 & 0 \\
\hline
\end{tabular}

Source: Table created by the author using data from USPTO.

Table 2 allow us to summarize some facts per the number of patents granted by USPTO to these wo country-cohorts for the eight manufacturing industries in the year 1990 and 2008. Chemical industry patents: Among the eight high income countries, Czech Republic had the largest growth in chemical patent (went up from o chemical patent in 1990 to 6 in 2008), followed by Australia (192 percent), Canada (100 percent), U.S. (20.6 percent), and France (7.1 percent) between 1990 and 2008. The countries that experienced a negative growth in chemical patent are Switzerland (-37.4 percent), Italy (-14.2 percent), and Poland (- 20 percent). All the eight developing countries showed growth in chemical patents. The growth rates were particularly notable for Russia (from o in 1990 to 35 in 2008), India (11 hundred percent), China ( 8 hundred 87 percent), and Malaysia (7 hundred percent).

Petroleum industry patents: Six countries out of eight high income countries showed negative growth in petroleum patent, when Czech Republic experienced growth (from o patents in 1990 to 1 patent 2008) and Poland's performance remained unchanged. Out of eight developing countries only South Africa experienced negative growth.

Electrical industry patents: Each of the eight high income countries experienced growth among which Australia (158 percent), Canada (69.2 percent), and USA (54 percent) experienced relatively higher percentile growth than others. Among eight developing countries, all but South Africa experienced 
growth among which China (3450 percent), India (from o in 1998 to 34 in 2008), Malaysia (1000 percent), Brazil (200 percent) are particularly notable.

Machinery industry patents: Out of eight high income countries half (Australia, Canada, Czech Republic, and Poland) experienced growth and other half (France, Italy, Switzerland, and U.S.) experienced negative growth. Poland had 400 percent growth between 1990 and 2008 when Switzerland experienced 38.1 percent negative growth.

Pharmaceutical industry patent: All the eight high income countries experienced growth rates with growth rates being particularly higher for Australia (625 percent), Canada (278 percent) and U.S. (126 percent). All eight developing countries except South Africa (-50 percent) posted growth rate in pharmaceutical industry patents. Two countries that posted significantly higher growth rates in the group are India ( 53 hundred percent) and China (21 hundred percent).

Plastic industry patents: Six out of eight high income countries experienced negative growth in patent count. One country (Poland) experienced growth rate and another country (Check Republic) maintained status quo (i.e., no positive or negative growth rate). On the other hand, except for two countries (Brazil: - 25 percent and South Africa: -50 percent), all other six developing countries experienced growth rate with growth rates being particularly higher for Mexico (100 percent), and India (50 percent).

Computer industry patents: All the eight high income countries and, eight developing countries in the study have seen growth in patents for this relatively new industry. Among the eight high income countries top three countries in terms of growth rate in computer industry patent counts are Australia (patents great by 255 hundred percent), Canada (1990 percent), and, USA ( 846 percent). Among eight developing countries, growth rates are particularly higher for China (108 hundred percent) and USA ( 5 hundred percent).

Textile industry patens: Out of eight high income countries, four (Australia, Italy, Czech Republic, Poland) experienced growth and the remaining four countries (Canada, France, Switzerland, U.S.) experienced negative growth rates. The growth rates were particularly higher for Australia (100 percent) and Italy (46 percent) and negative growth rates were particularly higher for Switzerland ( -53 percent) and France (32 percent). Out of eight developing countries, only China experienced a growth (167 percent), out of remaining seven countries Mexico posted a growth rate and the rest maintained status quo by not having any patents issued by USPTO between 1990 and 2008.

Figure 4A

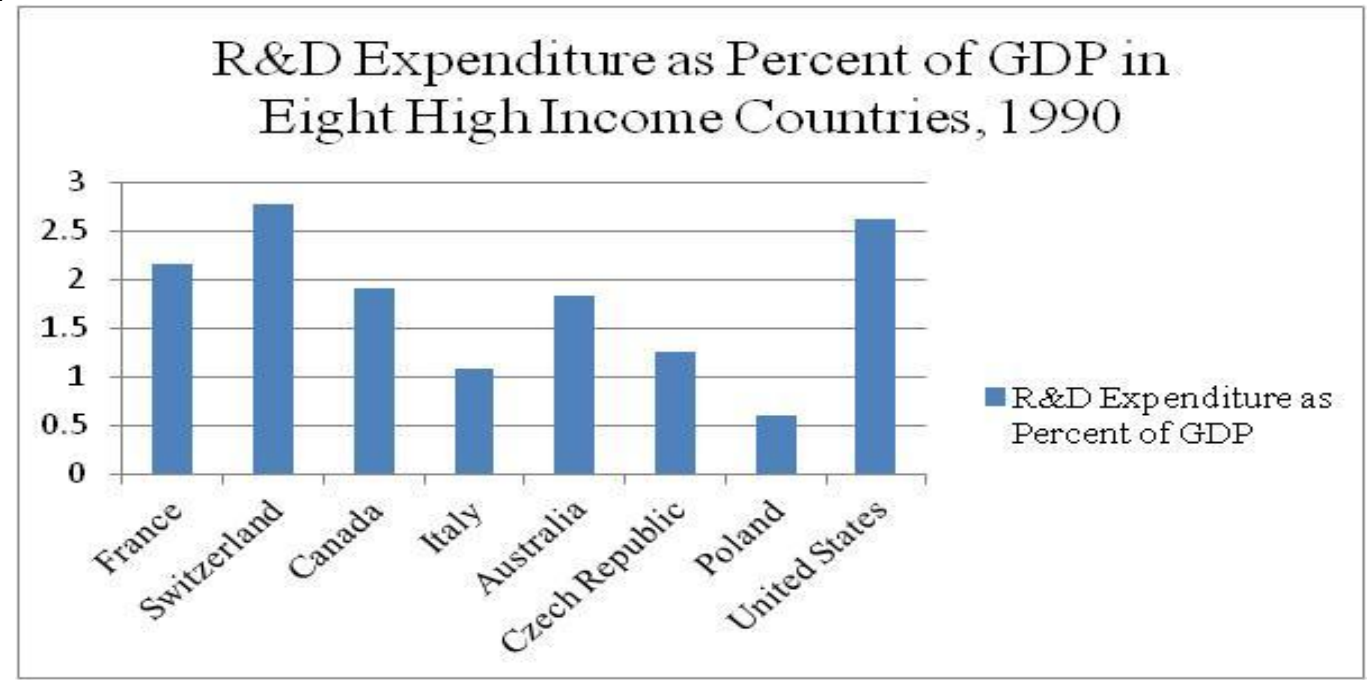

Source: Figure created by author using the USPTO database 
Figure 4B

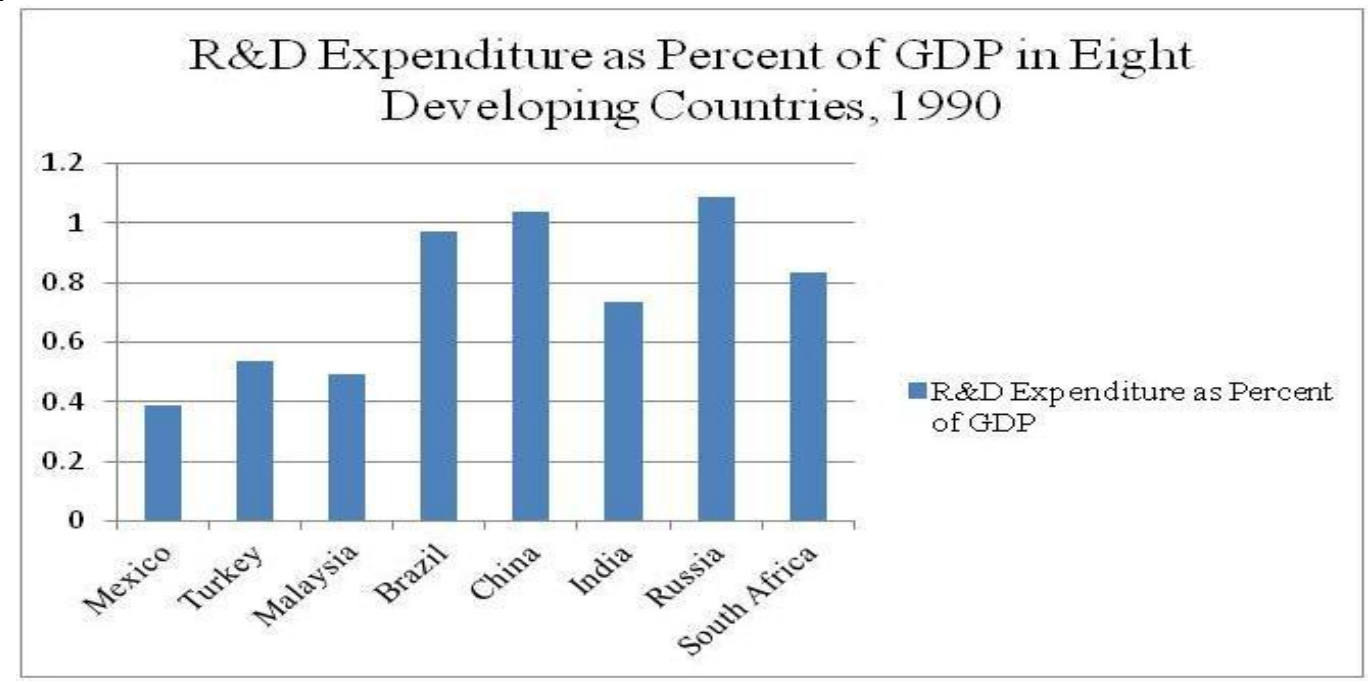

Source: Figure created by author using the USPTO database

Figure 5A

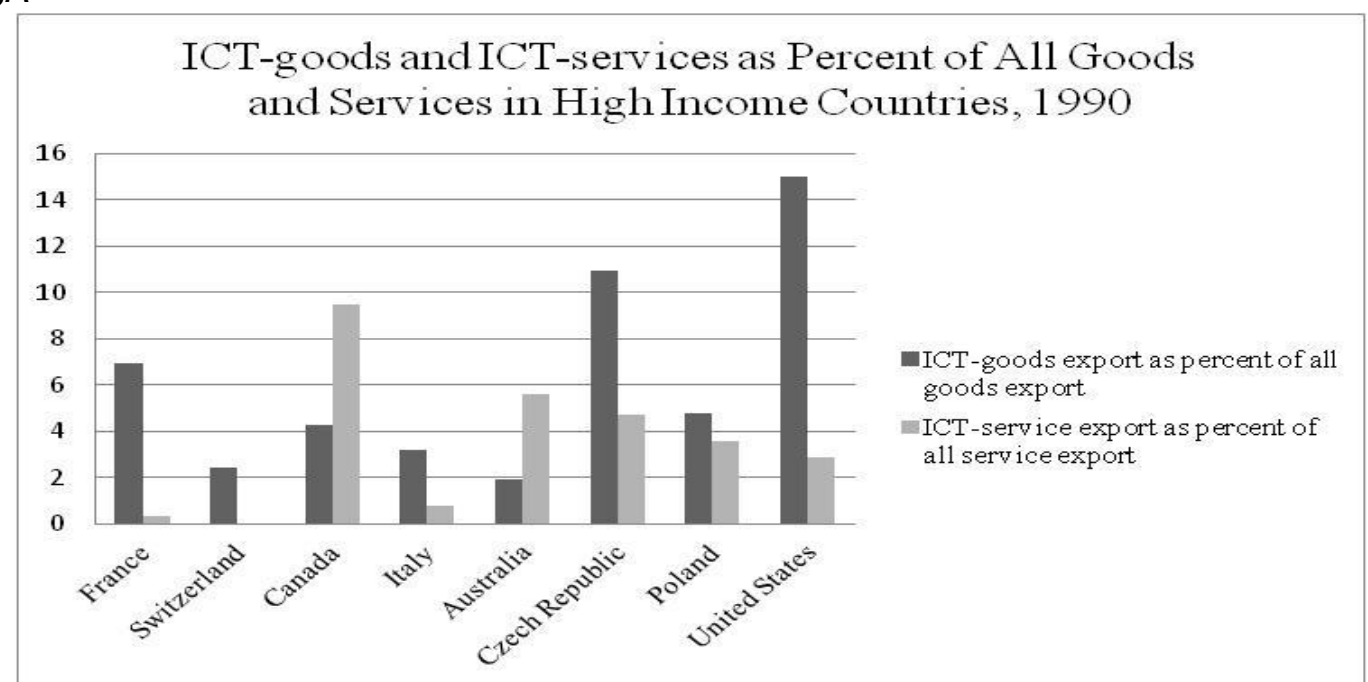

Source: Figure created by author using the USPTO database

Figure $5 \mathrm{~B}$

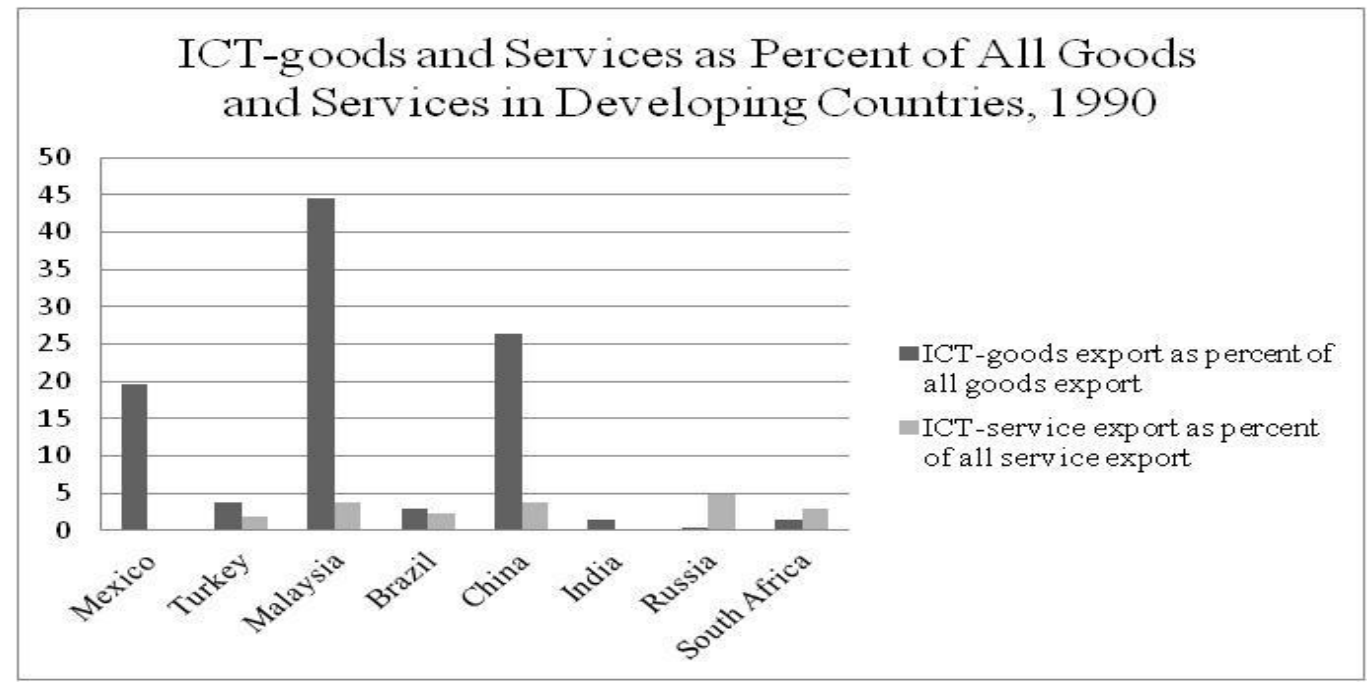

Source: Figure created by author using the USPTO database 
Figure 6A

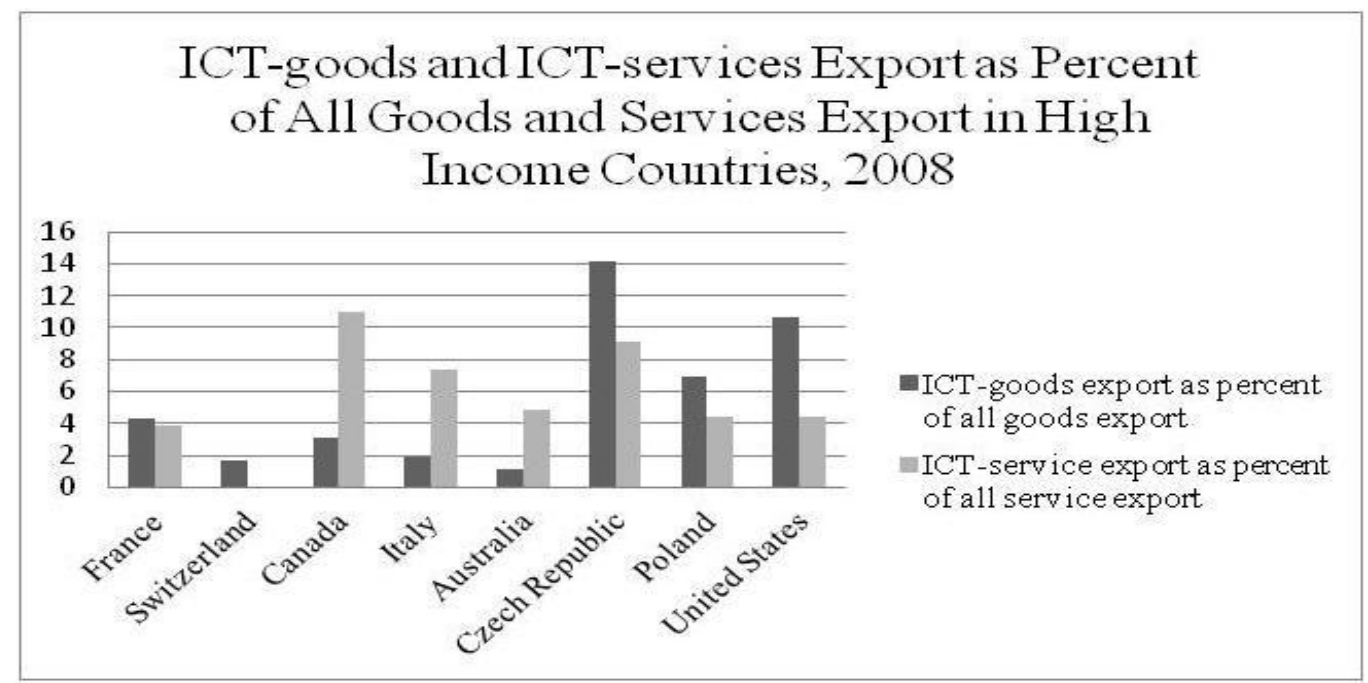

Source: Figure created by author using the USPTO database

Figure 6B

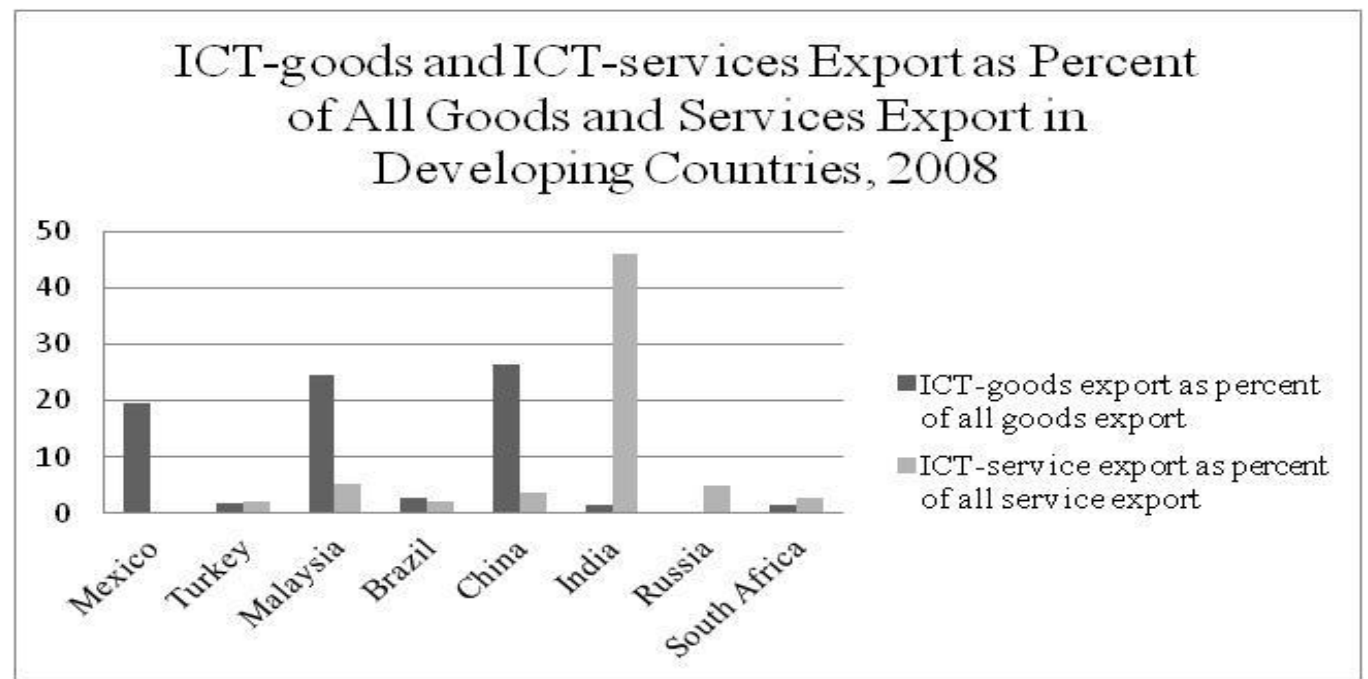

Source: Figure created by author using the USPTO database

Figure $7 \mathrm{~A}$

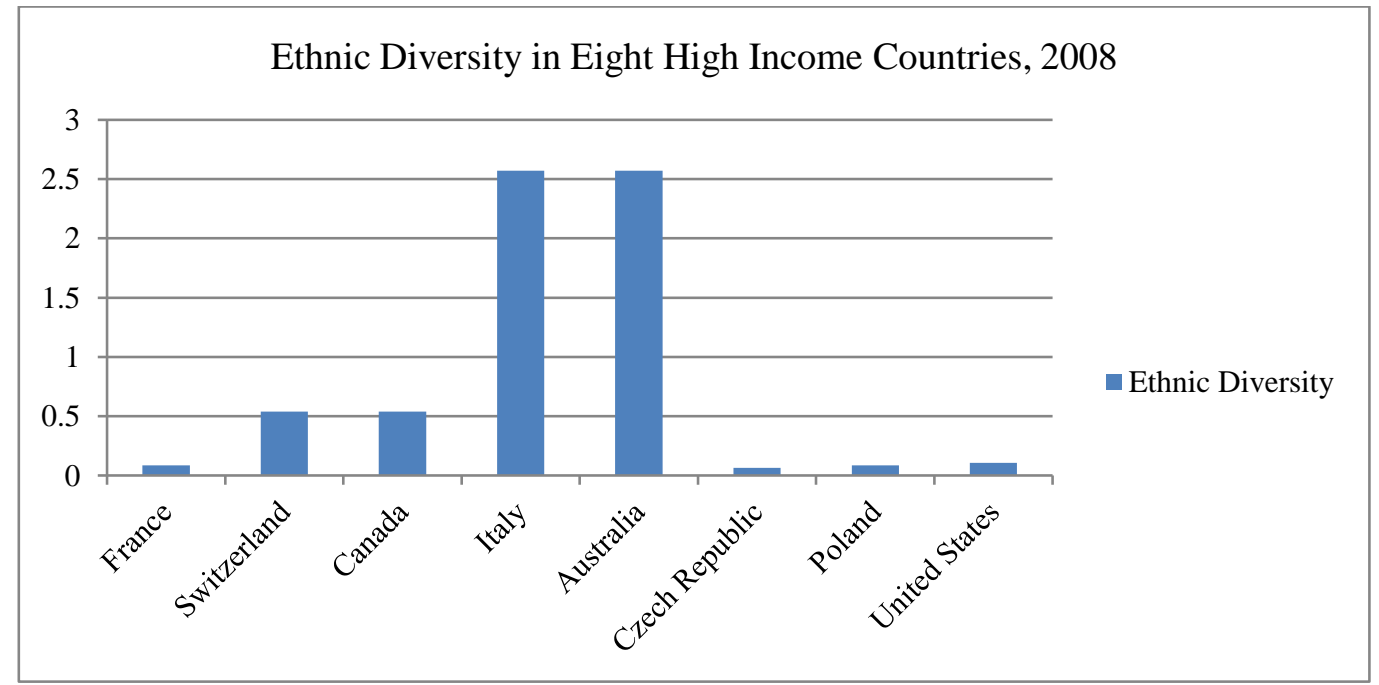

Source: Authors' creation using data from the CIA's 'world factbook' database. 
Figure $7 \mathrm{~B}$

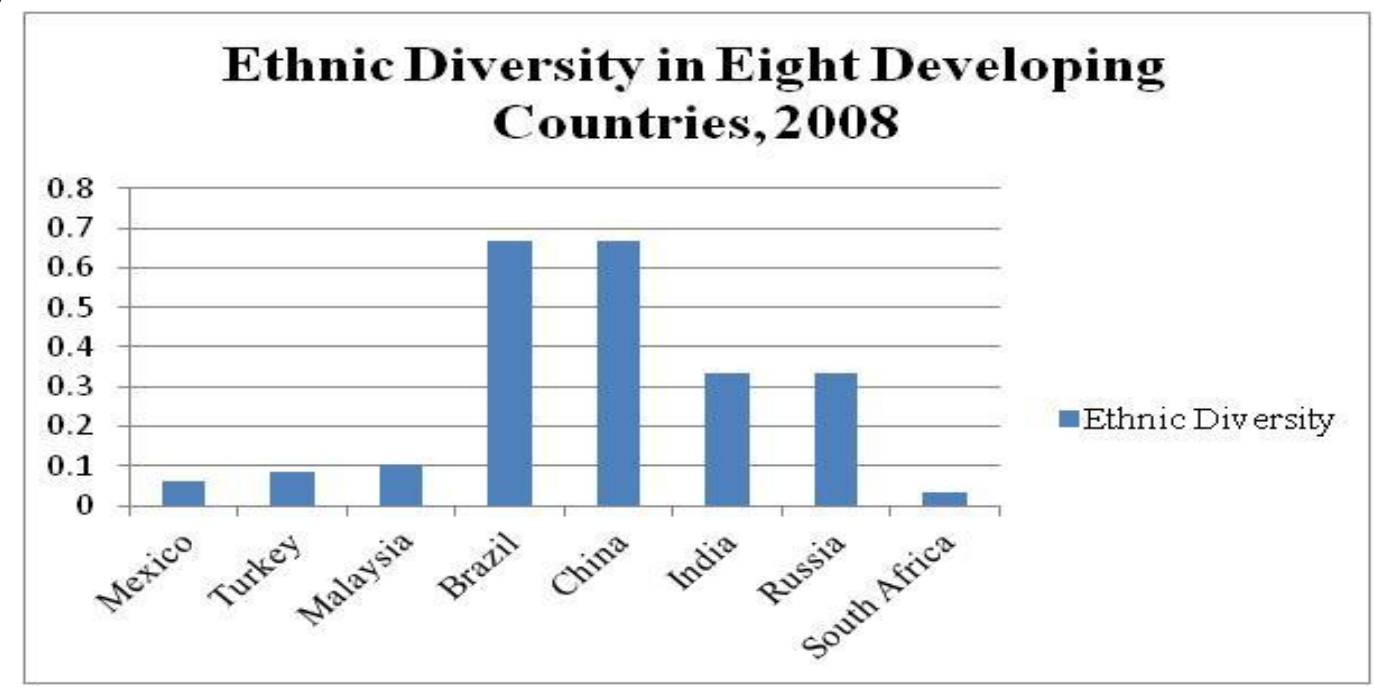

Source: Authors' creation using data from the CIA's 'world factbook' database.

Figure 8A

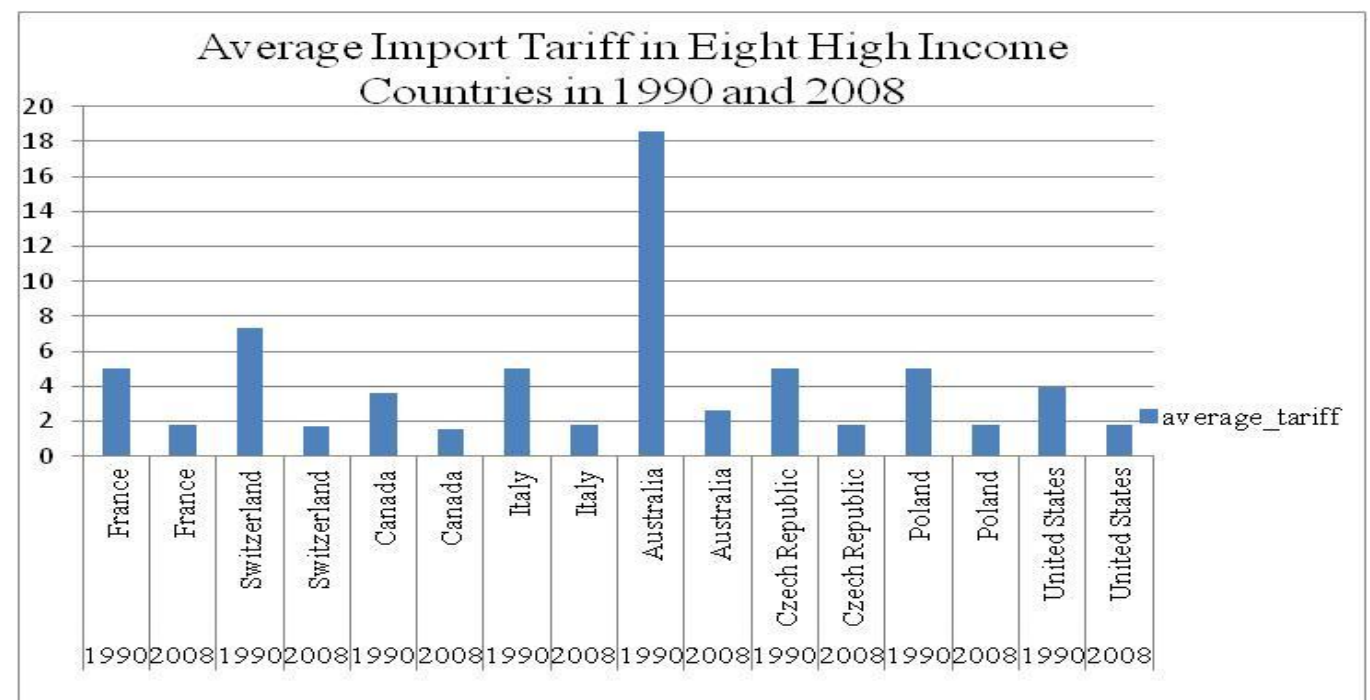

Source: Figure created by author using the USPTO database

Figure $8 \mathrm{~B}$

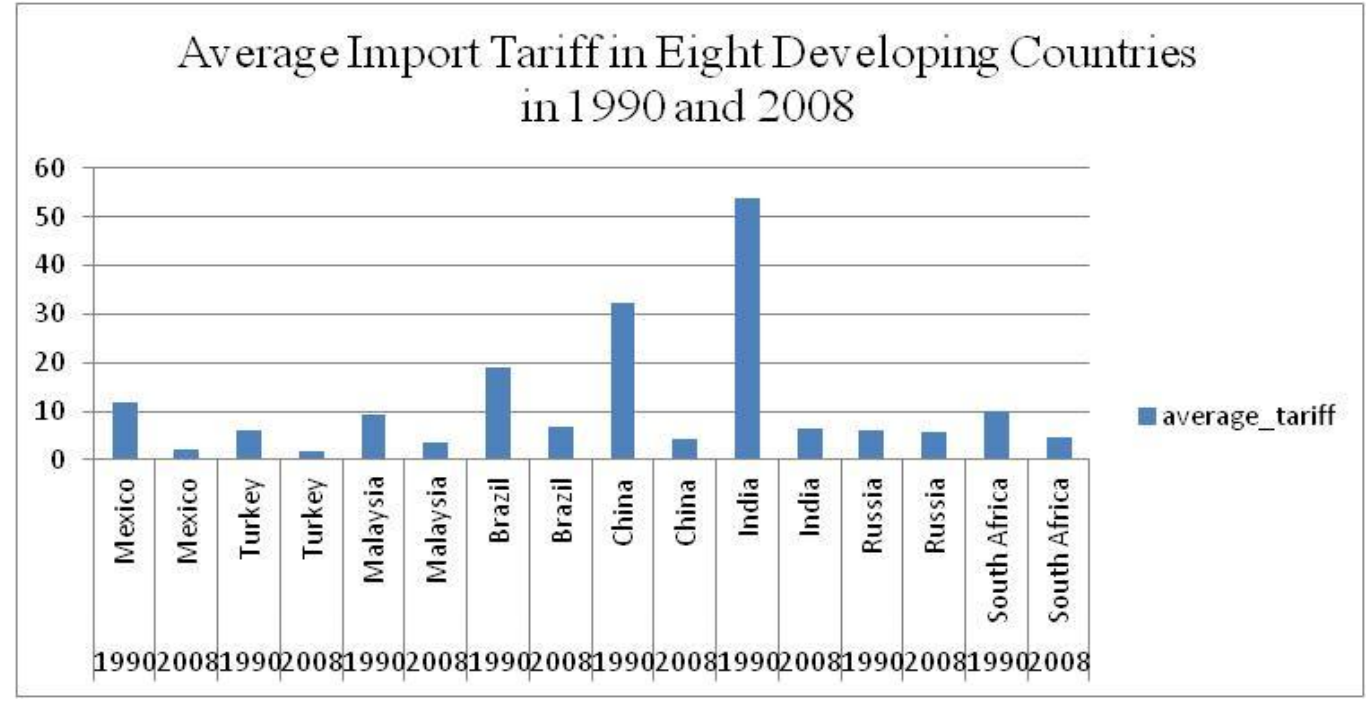

Source: Figure created by author using the USPTO database 
In Figures 4 through Figure 8 I graphically illustrate R\&D expenditure as share of GDP, ICT-goods and services exports relative to all goods and services exports, ethnic diversity, and average Tariff rates for eight high income countries, as well as, eight developing countries. Table 1 and 2 in the appendix section present correlations between key variables, Table 4 contains internet access data for these sixteen countries for the period of 1990-2011, and Table 5 reports descriptive statistics.

Table 4: Percent of population with internet access

\begin{tabular}{lrrrrrrrr}
\hline Country Name & 1990 & 1993 & 1996 & 1999 & 2002 & 2005 & 2008 & 2011 \\
\hline Eight High Income & & & & & & & & \\
Countries & & & & & & & & \\
Australia & 0.586 & 1.981 & 3.277 & 40.831 & 52.606 & - & 63.027 & 71.721 \\
Canada & 0.360 & 1.179 & 6.740 & 36.050 & 59.978 & 64.063 & 71.597 & 76.720 \\
Czech Republic & - & 0.581 & 1.939 & 6.817 & 14.682 & 34.273 & 35.218 & 62.686 \\
France & 0.051 & 0.574 & 2.509 & 8.862 & 25.483 & 34.945 & 41.391 & 68.185 \\
Italy & 0.018 & 0.123 & 1.025 & 14.368 & 27.328 & 29.171 & 35.038 & 44.574 \\
Poland & 0.000 & 0.129 & 1.288 & 5.411 & 9.906 & 24.866 & 38.810 & 53.259 \\
Switzerland & 0.592 & 2.153 & 4.543 & 33.965 & 54.933 & 64.817 & 69.892 & 78.429 \\
United States & 0.796 & 2.279 & 16.419 & 35.882 & 49.180 & 61.949 & 68.268 & 74.218 \\
\hline Eight Developing & & & & & & & & \\
Countries & & & & & & & & \\
\hline Brazil & 0.000 & 0.025 & 0.451 & 2.039 & 4.528 & 13.208 & 21.023 & 33.830 \\
China & 0.000 & 0.000 & 0.013 & 0.712 & 2.652 & 6.224 & 8.549 & 22.662 \\
India & 0.000 & 0.000 & 0.046 & 0.273 & 0.660 & 1.686 & 2.388 & 4.380 \\
Malaysia & 0.000 & 0.026 & 0.852 & 12.306 & 26.696 & 34.971 & 48.629 & 55.800 \\
Mexico & 0.000 & 0.028 & 0.200 & 1.857 & 7.038 & 12.900 & 17.210 & 21.710 \\
Russian Federation & 0.000 & 0.013 & 0.271 & 1.026 & 2.949 & 8.315 & 15.300 & 27.059 \\
South Africa & 0.000 & 0.120 & 0.888 & 4.233 & 6.414 & 7.086 & 7.583 & 8.521 \\
Turkey & 0.000 & 0.008 & 0.193 & 2.292 & 5.189 & 12.330 & 15.460 & 34.370 \\
\hline
\end{tabular}

Source: Authors' creation using data from the World Bank database.

Table 5: Descriptive statistics

\begin{tabular}{lrrrrr}
\hline Variable & Observation & Mean & Std. Dev. & Min & Max \\
\hline All Industry Patent Count & 304 & $5,108.918$ & $17,565.790$ & 0 & 89823.000 \\
Chemical Industry Patents & 304 & 668.174 & $2,158.867$ & 0 & $11,727.000$ \\
Petroleum Industry Patents & 304 & 79.253 & 265.791 & 0 & $1,378.000$ \\
Electrical Industry Patents & 304 & 322.092 & $1,103.142$ & 0 & $5,702.000$ \\
Machineries Industry Patents & 304 & 743.618 & $2,408.670$ & 0 & $11,817.000$ \\
Pharmaceutical Industry Patents & 304 & 209.033 & 719.799 & 0 & $4,212.000$ \\
Plastic Industry Patents & 304 & 193.816 & 663.411 & 0 & $3,425.000$ \\
Computer Industry Patents & 304 & 437.970 & $1,818.233$ & 0 & $13,086.000$ \\
Textile Industry Patents & 304 & 62.286 & 218.562 & 0 & $1,290.000$ \\
Percent of population with Internet & 304 & 17.173 & 22.051 & 0 & 78.429 \\
access & 304 & 0.472 & 0.612 & 0.034 & 2.571 \\
Ethnic Diversity & 304 & $3,533.640$ & $2,224.272$ & 382.169 & $8,424.313$ \\
Electricity Consumption Per Capita & 257 & 37.438 & 24.136 & 5.2 & 97.976 \\
Tertiary Education & 304 & 1.272 & 0.745 & 0.216 & 2.995 \\
R\&D expenditure as percent of GDP & 304 & 0.617 & 0.419 & 0.158 & 2.204 \\
$\begin{array}{l}\text { Openness to International Trade } \\
\text { Maximum Corporate Income Tax }\end{array}$ & 302 & 33.441 & 4.243 & 21.000 & 45.000 \\
$\begin{array}{l}\text { Rate } \\
\text { Maximum Personal income Tax }\end{array}$ & & & & & \\
Rate & 304 & 34.888 & 8.866 & 13.000 & 50.000 \\
\hline
\end{tabular}




\begin{tabular}{lrrrrr}
\hline GNI Per capita & 304 & $13,595.350$ & $14,058.590$ & 330.000 & $58,300.000$ \\
ICT goods export as percent of all & 304 & 9.357 & 11.727 & 0.167 & 52.681 \\
$\begin{array}{l}\text { good exports } \\
\text { ICT service export as percent of all }\end{array}$ & 266 & 6.895 & 11.113 & 0.370 & 53.740 \\
$\begin{array}{l}\text { service exports } \\
\text { Average Import Tariff Rate }\end{array}$ & 304 & 7.155 & 6.967 & 1.000 & 53.950 \\
\hline
\end{tabular}

\section{Results and discussion}

Table 6 and Table 8 present regression results where dependent variables are per capita patent issued by USPTO and Table 7 presents regression results where the dependent variable is number of patent applications submitted per ten thousand people. First, I discuss the general variables that are present in both determinant model and globalization model and then I will comment on the variables included in the globalization model in the light of a priori hypotheses informed by existing strands of literature or personal intuitions as applicable.

Table 6: Determinant and globalization model regressions of patent count

\begin{tabular}{|c|c|c|c|c|c|c|}
\hline & & Random Effect & & Fixed Effect & & GLS \\
\hline & $\begin{array}{l}\text { Determinant } \\
\text { model }\end{array}$ & $\begin{array}{r}\text { Globalization } \\
\text { model }\end{array}$ & $\begin{array}{r}\text { Determinant } \\
\text { model }\end{array}$ & $\begin{array}{r}\text { Globalization } \\
\text { model }\end{array}$ & $\begin{array}{r}\text { Determinant } \\
\text { model }\end{array}$ & $\begin{array}{r}\text { Globalization } \\
\text { model }\end{array}$ \\
\hline Ethnic Diversity & $\begin{array}{r}0.300 * * * \\
(0.094)\end{array}$ & $\begin{array}{l}-0.119 \\
(0.171)\end{array}$ & $\begin{array}{r}0.001 \\
(0.001)\end{array}$ & $\begin{array}{r}0.001 \\
(0.001)\end{array}$ & $\begin{array}{r}0.041 \\
(0.044)\end{array}$ & $\begin{array}{r}0.032 \\
(0.052)\end{array}$ \\
\hline Diversity $\times$ Dev & $\begin{array}{r}0.464^{* * *} \\
(0.138)\end{array}$ & $\begin{array}{r}0.951 * * * \\
(0.224)\end{array}$ & $\begin{array}{r}0.001 \\
(0.001)\end{array}$ & $\begin{array}{r}0.001 \\
(0.001)\end{array}$ & $\begin{array}{r}0.718 * * * \\
(0.094)\end{array}$ & $\begin{array}{r}0.577^{* * *} \\
(0.118)\end{array}$ \\
\hline Capita & & & & & & \\
\hline $\begin{array}{l}\text { Electricity Use } \\
\text { (Electricity) }\end{array}$ & $\begin{array}{r}0.929^{* * *} \\
(0.112)\end{array}$ & $\begin{array}{r}2.286 * * * \\
(0.277)\end{array}$ & (1.733) & $\begin{array}{r}-4.798 * * \\
(2.173)\end{array}$ & $\begin{array}{r}1.353^{* * *} \\
(0.077)\end{array}$ & $\begin{array}{r}1.544^{* * *} \\
(0.157)\end{array}$ \\
\hline Enrollment in & $\begin{array}{l}-0.069 \\
(0.125)\end{array}$ & $\begin{array}{r}-0.559 * * * \\
(0.181)\end{array}$ & $\begin{array}{r}2.815 \\
(1.954)\end{array}$ & $\begin{array}{r}6.988 * * \\
(2.514)\end{array}$ & $\begin{array}{r}-0.235^{* * *} \\
(0.070)\end{array}$ & $\begin{array}{r}-0.561 * * * \\
(0.084)\end{array}$ \\
\hline $\begin{array}{l}\text { Tertiary Education } \\
\text { (TertiaryEd) }\end{array}$ & $\begin{array}{r}0.351 \\
(0.236)\end{array}$ & $\begin{array}{r}0.236 \\
(0.175)\end{array}$ & $\begin{array}{r}0.062 \\
(0.132)\end{array}$ & $\begin{array}{l}0.458 * * \\
(0.180)\end{array}$ & $\begin{array}{l}-0.080 \\
(0.091)\end{array}$ & $\begin{array}{r}0.017 \\
(0.052)\end{array}$ \\
\hline $\begin{array}{l}\text { Tertiary Education } \\
\times \text { Dev }\end{array}$ & $\begin{array}{r}0.664 \\
(0.541)\end{array}$ & $\begin{array}{r}-0.589 \\
(0.504)\end{array}$ & $\begin{array}{r}1.188 \\
(0.759)\end{array}$ & $\begin{array}{r}0.451 \\
(0.650)\end{array}$ & $\begin{array}{r}1.347 * * * \\
(0.440)\end{array}$ & $\begin{array}{l}-0.627 \\
(0.733)\end{array}$ \\
\hline $\begin{array}{l}\text { R\&D Expenditure } \\
\text { as Percent of GDP } \\
(R \& D)\end{array}$ & $\begin{array}{r}1.413^{* * *} \\
(0.244)\end{array}$ & $\begin{array}{r}0.061 \\
(0.326)\end{array}$ & $\begin{array}{l}1.230 * * * \\
(0.294)\end{array}$ & $\begin{array}{l}1.865^{* *} \\
(0.704)\end{array}$ & $\begin{array}{r}3.512 * * * \\
(0.174)\end{array}$ & $\begin{array}{r}0.119 \\
(0.103)\end{array}$ \\
\hline $\begin{array}{l}\text { R\&D Expenditure } \\
\times \text { Dev }\end{array}$ & $\begin{array}{r}-0.961 * * * \\
-0.316\end{array}$ & $\begin{array}{c}0.775 * \\
(0.398)\end{array}$ & $\begin{array}{l}-1.191 * * \\
(0.454)\end{array}$ & $\begin{array}{l}-1.216 * \\
(0.626)\end{array}$ & $\begin{array}{r}-3.480 * * * \\
(0.200)\end{array}$ & $\begin{array}{r}0.339 * * \\
(0.173)\end{array}$ \\
\hline Trade Openness & $\begin{array}{r}-0.439 * * \\
(0.190)\end{array}$ & $\begin{array}{r}0.664^{* * *} \\
(0.257)\end{array}$ & $\begin{array}{l}1.859^{* *} \\
(0.670)\end{array}$ & $\begin{array}{r}0.369 \\
(0.355)\end{array}$ & $\begin{array}{r}-0.161 \\
(0.102)\end{array}$ & $\begin{array}{l}-0.181^{*} \\
(0.100)\end{array}$ \\
\hline $\begin{array}{l}\text { Trade Openness } \times \\
\text { Dev }\end{array}$ & $\begin{array}{r}1.238 * * * \\
(0.241)\end{array}$ & $\begin{array}{r}-0.120 \\
(0.374)\end{array}$ & $\begin{array}{r}-1.032 \\
(0.880)\end{array}$ & $\begin{array}{r}0.292 \\
(0.971)\end{array}$ & $\begin{array}{r}0.778 * * * \\
(0.139)\end{array}$ & $\begin{array}{l}1.111 * * * \\
(0.239)\end{array}$ \\
\hline $\begin{array}{l}\text { Maximum } \\
\text { Corporate Income } \\
\text { Tax Rate (CIT) }\end{array}$ & $\begin{array}{r}0.073^{* * *} \\
(0.012)\end{array}$ & $\begin{array}{l}0.035^{*} \\
(0.020)\end{array}$ & $\begin{array}{l}0.016 * \\
(0.008)\end{array}$ & $\begin{array}{r}-0.038 * * \\
(0.016)\end{array}$ & $\begin{array}{r}0.048 * * * \\
(0.007)\end{array}$ & $\begin{array}{l}0.013^{*} \\
(0.007)\end{array}$ \\
\hline
\end{tabular}




\begin{tabular}{|c|c|c|c|c|c|c|}
\hline $\begin{array}{l}\text { Corporate Income } \\
\text { Tax } \times \text { Dev }\end{array}$ & $\begin{array}{r}0.036 \\
(0.026)\end{array}$ & $\begin{array}{l}-0.020 \\
(0.033)\end{array}$ & $\begin{array}{r}0.024 \\
(0.032)\end{array}$ & $\begin{array}{r}0.044 \\
(0.039)\end{array}$ & $\begin{array}{r}0.047^{* * *} \\
(0.014)\end{array}$ & $\begin{array}{l}-0.020 \\
(0.018)\end{array}$ \\
\hline Max. Personal & & & & & & \\
\hline $\begin{array}{l}\text { Income Tax Rate } \\
\text { (PIT) }\end{array}$ & $0.048 * * *$ & 0.009 & 0.006 & 0.026 & 0.006 & 0.001 \\
\hline & $(0.014)$ & $(0.023)$ & $(0.007)$ & $(0.016)$ & $(0.007)$ & $(0.006)$ \\
\hline $\begin{array}{l}\text { Personal Income } \\
\text { Tax } \times \text { Dev }\end{array}$ & $-0.033^{* *}$ & 0.039 & -0.008 & -0.022 & $0.026 * *$ & $0.032 * * *$ \\
\hline & $(0.015)$ & $(0.027)$ & $(0.009)$ & $(0.014)$ & $(0.010)$ & $(0.012)$ \\
\hline $\begin{array}{l}\text { Internet Access } \\
\text { (Internet) }\end{array}$ & & 0.001 & & $0.015^{* *}$ & & $0.006 * * *$ \\
\hline & & $(0.004)$ & & $(0.007)$ & & $(0.001)$ \\
\hline Internet $\times$ Dev & & $\begin{array}{l}0.013^{* *} \\
(0.006)\end{array}$ & & $\begin{array}{r}-0.010 \\
(0.014)\end{array}$ & & $\begin{array}{r}0.016 * * * \\
(0.005)\end{array}$ \\
\hline ICT Goods Export & & $\begin{array}{r}0.087^{* * *} \\
(0.026)\end{array}$ & & $\begin{array}{r}0.024 \\
(0.032)\end{array}$ & & $\begin{array}{r}0.084^{* * *} \\
(0.009)\end{array}$ \\
\hline $\begin{array}{l}\text { ICT Goods Export } \\
\times \text { Dev }\end{array}$ & & $-0.090 * * *$ & & -0.038 & & $-0.086 * * *$ \\
\hline & & $(0.026)$ & & $(0.030)$ & & (0.012) \\
\hline ICT Service Export & & $\begin{array}{r}-0.095^{* *} \\
(0.043)\end{array}$ & & $\begin{array}{r}-0.069^{* *} \\
(0.031)\end{array}$ & & $\begin{array}{r}-0.061^{* * * *} \\
(0.012)\end{array}$ \\
\hline $\begin{array}{l}\text { ICT Service Export } \\
\times \text { Dev }\end{array}$ & & $0.141^{* * *}$ & & $0.086 * *$ & & $0.077^{* * *}$ \\
\hline & & $(0.043)$ & & $(0.033)$ & & $(0.014)$ \\
\hline $\begin{array}{l}\text { Average Import } \\
\text { Tariff }\end{array}$ & & -0.024 & & -0.032 & & $-0.024 * * *$ \\
\hline & & $(0.023)$ & & $(0.024)$ & & $(0.007)$ \\
\hline $\begin{array}{l}\text { Average Import } \\
\text { Tariff } \times \text { Dev }\end{array}$ & & 0.022 & & 0.042 & & -0.012 \\
\hline & & $(0.025)$ & & $(0.030)$ & & $(0.008)$ \\
\hline $\begin{array}{l}\text { Developing } \\
\text { Countries }\end{array}$ & & $2.025^{* * *}$ & & 0.001 & & $2.826 * * *$ \\
\hline & & (0.754) & & $(0.001)$ & & $(0.357)$ \\
\hline T95 & & $\begin{array}{r}0.437^{* * *} \\
(0.139)\end{array}$ & & $\begin{array}{r}0.609 * * \\
(0.232)\end{array}$ & & $\begin{array}{r}0.049 \\
(0.042)\end{array}$ \\
\hline Observations & 291 & 253 & 291 & 253 & 291 & 253 \\
\hline R-squared & 0.944 & 0.966 & 0.523 & 0.641 & - & - \\
\hline $\begin{array}{l}\text { Wald Chi Squared } \\
\text { Prob > Chi Squared }\end{array}$ & - & - & - & & $\begin{array}{r}32519.890 \\
0.000\end{array}$ & $\begin{array}{r}35485.29 \\
0.000\end{array}$ \\
\hline
\end{tabular}

Note: Robust standard errors are given in parentheses and statistical significance of the estimated coefficients are given at the conventional $10 \%(*), 5 \%(* *)$, and $1 \%(* * *)$ levels. The binary variable Developing takes on a value of 1 for developing countries and o otherwise. Binary variable T95 takes on a value of 1 for years $>=1995$ and 0 otherwise. Trade openness is measured as ratio of value of export plus import to GDP. In the Generalized Least Square model, I control for autocorrelation and heteroskedasticity. ICT implies Information and Communication Technologies.

Table 7: Determinant and globalization model regressions of patent application per ten thousand residents of incumbent countries

\begin{tabular}{|c|c|c|c|c|c|c|}
\hline & \multicolumn{2}{|r|}{ Random Effect } & \multicolumn{2}{|r|}{ Fixed Effect } & \multicolumn{2}{|r|}{ GLS } \\
\hline & $\begin{array}{r}\text { Determinant } \\
\text { model }\end{array}$ & $\begin{array}{r}\text { Globalization } \\
\text { model }\end{array}$ & $\begin{array}{r}\text { Determinant } \\
\text { model }\end{array}$ & $\begin{array}{r}\text { Globalization } \\
\text { model }\end{array}$ & $\begin{array}{r}\text { Determinant } \\
\text { model }\end{array}$ & $\begin{array}{r}\text { Globalization } \\
\text { model }\end{array}$ \\
\hline Ethnic Diversity & $\begin{array}{r}0.243 \\
(0.193)\end{array}$ & $\begin{array}{r}0.191^{*} \\
(0.105)\end{array}$ & & & $\begin{array}{r}0.426 * * * \\
(0.009)\end{array}$ & $\begin{array}{r}0.153^{* * *} \\
(0.059)\end{array}$ \\
\hline Diversity $\times$ Dev & 0.143 & $1.309^{* * *}$ & & & $0.325^{* * *}$ & 1.074 \\
\hline
\end{tabular}


Per Capita

Electricity Use (Electricity)

Electricity $\times$ Dev

Enrollment in

Tertiary

Education

(TertiaryEd)

Tertiary

Education $\times$ Dev

R\&D Expenditure as Percent of GDP (R\&D)

$R \& D$ Expenditure $\times$ Dev

Trade Openness

Trade Openness

$\times$ Dev

Maximum

Corporate Income Tax Rate (CIT)

Corporate

Income Tax $\times$ Dev

Max. Personal Income Tax Rate (PIT)

Personal Income

Tax $\times$ Dev

Internet Access

(Internet)

Internet $\times$ Dev

ICT Goods Export

ICT Goods Export

$\times$ Dev

$$
(0.526) \quad(0.351)
$$

$(0.054)$

(0.885)

$\begin{array}{rrrrrr}0.000 & 1.379 * * * & 0.001 & -0.096 & 0.001 & 1.332^{* * *} \\ (0.000) & (0.350) & (0.001) & (0.899) & (0.001) & (0.234) \\ & -0.300^{* *} & & 0.125 & & -0.252^{* * *} \\ & (0.135) & & (1.821) & & (0.072)\end{array}$

$\begin{array}{rrr}-0.256^{* *} & 0.025 & -0.274^{* *} \\ (0.113) & (0.143) & (0.113)\end{array}$

$-0.159$

$-0.185^{* * *}$

$-0.074$

(0.165)

(0.056)

$$
0.603
$$

(0.389)

0.664

1.485

$0.574 * *$

0.728

(1.419)

(0.384)

(1.597)

(0.225)

(1.044)

$$
-1.034
$$

0.121

$-1.252$

$-0.338$

$0.670 * * *$

0.161

(0.999)

(0.191)

(1.112)

$(0.436)$

$(0.022)$

(0.112)

$\begin{array}{ll}1.237 & -0.336\end{array}$

1.419

$-0.024$

$0.383 * * *$

$-0.429$

(1.085)

(0.209)

(1.177)

$(0.427)$

(0.093)

$(0.308)$

$-0.251$

$-0.163$

0.034

$0.138 * * *$

$-0.219 * *$

$(0.263)$

(0.252)

(0.291)

$(0.041)$

(0.101)

$1.906 * * *$

0.048

$1.862 * * *$

0.068

$1.442 * * *$

0.419

(0.601)

(0.298)

(0.616)

(0.443)

(0.074)

(0.514)

$\begin{array}{lll}0.017 & -0.022 & 0.012 \\ (0.011) & (0.022) & (0.012)\end{array}$

0.016

0.003

$-0.005$

(0.011)

(0.012)

(0.014)

$(0.003)$

(0.006)

$$
\begin{array}{rr}
0.018 & 0.106 * * * \\
(0.028) & (0.020)
\end{array}
$$

0.026

0.059

$0.028 * * *$

$0.103 * * *$

(0.037)

(0.032)

(0.004)

(0.018)

$$
\begin{array}{r}
0.005 \\
(0.017)
\end{array}
$$

$-0.007$

$-0.014$

$0.004^{* * *}$

0.001

$$
\begin{array}{r}
-0.014 \\
(0.016)
\end{array}
$$

(0.009)

(0.014)

(0.001)

(0.004)

$-0.040 * * *$

$-0.014 \quad-0.025^{*}$

$-0.017$

$-0.012 * * *$

$-0.022 * *$

(0.015)

(0.016)

(0.013)

(0.015)

(0.003)

(0.009)

0.002

$-0.001$

$0.003^{* *}$

(0.004)

(0.001)

$-0.009$

$-0.014 * *$

(0.009)

(0.006)

$-0.102 * *$

$-0.101 * * *$

(0.035)

(0.010)

(0.026)

0.039

$-0.009$

(0.029) 


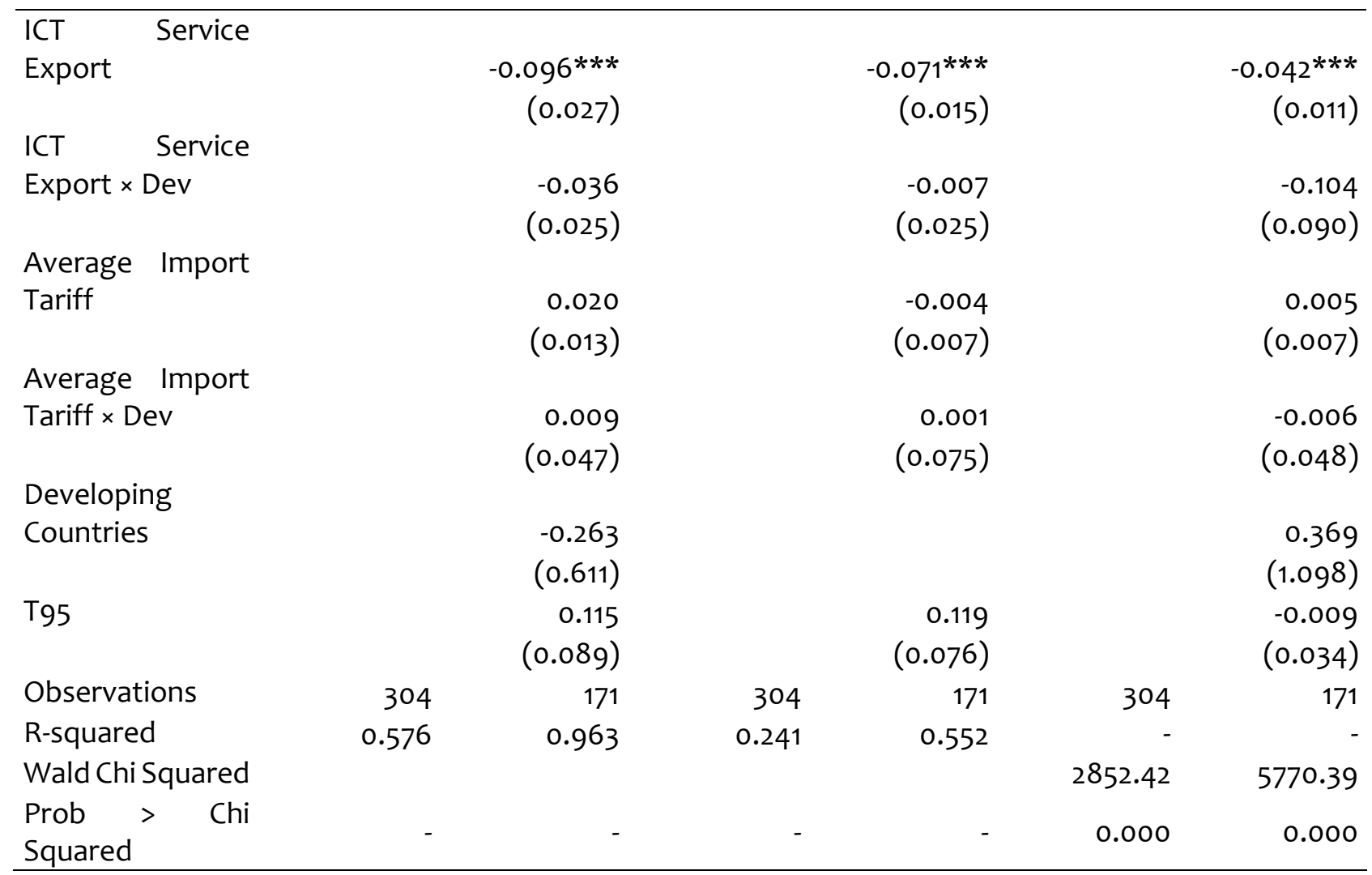

Note: Robust standard errors are given in parentheses and statistical significance of the estimated coefficients are given at the conventional $10 \%(*), 5 \%(* *)$, and $1 \%(* * *)$ levels. The binary variable Developing takes on a value of 1 for developing countries and o otherwise. Binary variable T95 takes on a value of 1 for years $>=1995$ and 0 otherwise. Trade openness is measured as ratio of value of export plus import to GDP. In the Generalized Least Square model, I control for autocorrelation and heteroskedasticity. ICT implies Information and Communication Technologies.

Table 8: Eight industry globalization model GLS regression results

$\begin{array}{crrrr}\text { Chemical Petroleum } \begin{array}{r}\text { Electric Machinery Pharmace } \\ \text { Equipment }\end{array} & \text { Plastic } & \text { Computer } & \text { Textile } \\ \text { utical } & & & \end{array}$

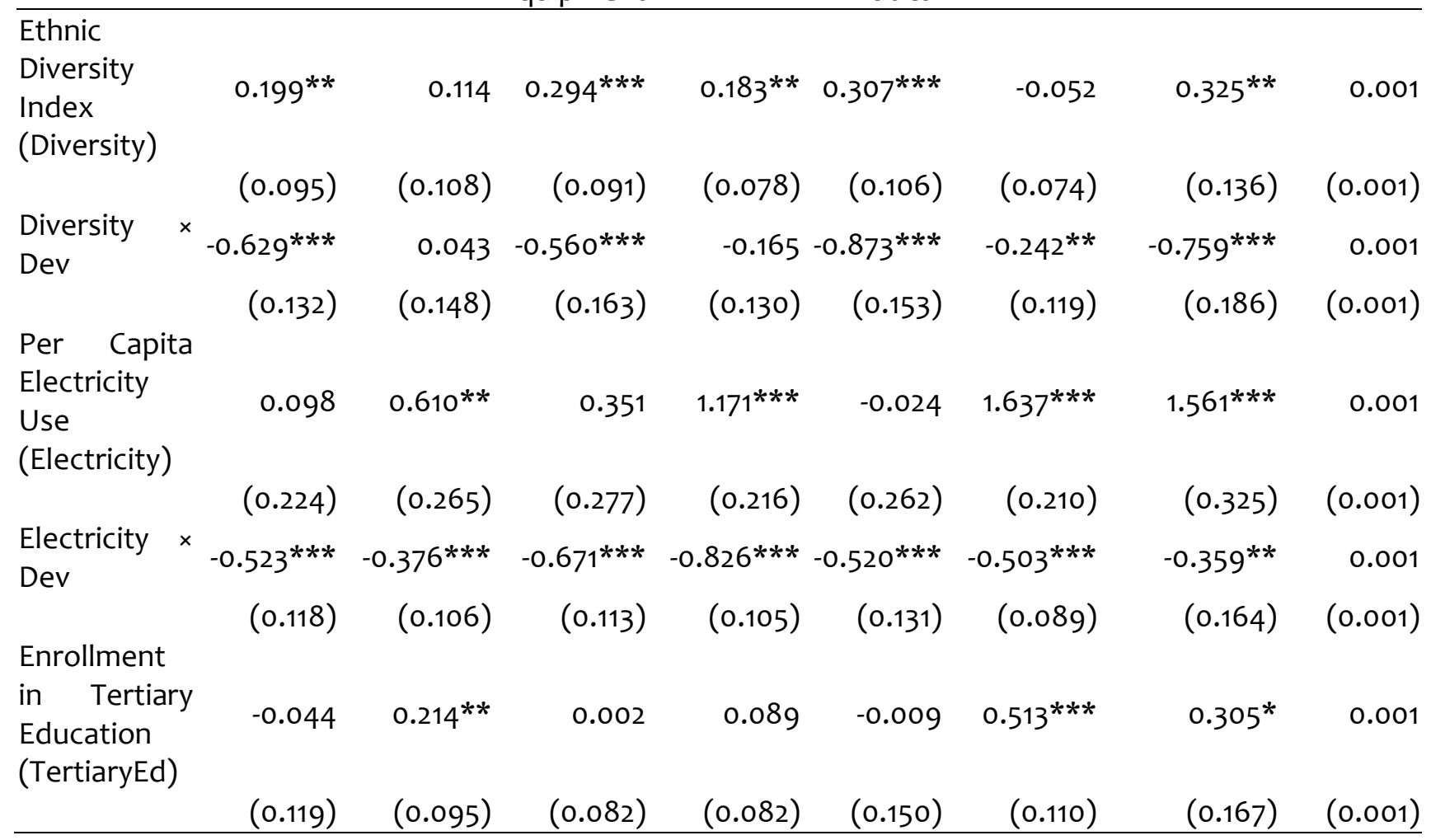




\begin{tabular}{|c|c|c|c|c|c|c|c|c|}
\hline Tertiary & & & & & & & & \\
\hline Education & 0.787 & -0.027 & -0.478 & -0.408 & 0.542 & $-1.362 * * *$ & 0.176 & 0.001 \\
\hline Dev & $(0.542)$ & $(0.539)$ & $(0.471)$ & $(0.696)$ & $(0.431)$ & $(0.509)$ & $(0.749)$ & $(0.001)$ \\
\hline$R \& D$ & & & & & & & & \\
\hline $\begin{array}{l}\text { Expenditure } \\
\text { as Percent of }\end{array}$ & $0.360 *$ & $1.485^{* * *}$ & 0.072 & $-1.276 * * *$ & $0.572 * *$ & $-0.275^{*}$ & 0.409 & 0.001 \\
\hline & (0.191) & $(0.200)$ & $(0.181)$ & $(0.154)$ & $(0.222)$ & $(0.159)$ & $(0.298)$ & $(0.001)$ \\
\hline$R \& D$ & & & & & & & & \\
\hline $\begin{array}{l}\text { Expenditure } \\
\times \text { Dev }\end{array}$ & $0.695 * * *$ & $-0.599 *$ & $1.922 * * *$ & $2.280 * * *$ & 0.293 & 0.199 & $1.474 * * *$ & 0.001 \\
\hline & $(0.258)$ & $(0.326)$ & $(0.396)$ & $(0.253)$ & $(0.297)$ & $(0.304)$ & $(0.401)$ & $(0.001)$ \\
\hline $\begin{array}{l}\text { Trade } \\
\text { Openness }\end{array}$ & $-1.017 * * *$ & $-1.917 * * *$ & $-0.835^{* * *}$ & $-0.758 * * *$ & $-1.301 * * *$ & $-1.424 * * *$ & $-1.180 * * *$ & 0.001 \\
\hline & $(0.189)$ & $(0.179)$ & $(0.163)$ & $(0.153)$ & $(0.214)$ & $(0.146)$ & $(0.297)$ & $(0.001)$ \\
\hline Trade & & & & & & & & \\
\hline $\begin{array}{l}\text { Openness } \times \\
\text { Dev }\end{array}$ & $0.808 * *$ & $2.217^{* * *}$ & $0.785^{* *}$ & 0.397 & $1.247 * * *$ & 0.051 & -0.045 & 0.001 \\
\hline & $(0.342)$ & $(0.372)$ & $(0.378)$ & $(0.325)$ & $(0.370)$ & $(0.334)$ & $(0.508)$ & $(0.001)$ \\
\hline Maximum & & & & & & & & \\
\hline $\begin{array}{l}\text { Corporate } \\
\text { Income Tax }\end{array}$ & 0.016 & -0.005 & -0.001 & 0.006 & -0.002 & 0.002 & $-0.069 * * *$ & $-0.060 * * *$ \\
\hline Rate & $(0.014)$ & $(0.011)$ & $(0.011)$ & $(0.010)$ & $(0.016)$ & $(0.012)$ & $(0.021)$ & $(0.001)$ \\
\hline Corp & & & & & & & & \\
\hline $\begin{array}{l}\text { Income Tax } x \\
\text { Dev }\end{array}$ & -0.030 & $-0.037 * *$ & 0.023 & 0.012 & 0.020 & -0.005 & -0.032 & 0.001 \\
\hline & $(0.024)$ & $(0.016)$ & $(0.027)$ & $(0.023)$ & $(0.027)$ & $(0.018)$ & $(0.033)$ & $(0.001)$ \\
\hline Max. & & & & & & & & \\
\hline $\begin{array}{l}\text { Personal } \\
\text { Income Tax } \\
\text { Rate (PIT) }\end{array}$ & -0.016 & $-0.046 * * *$ & 0.004 & 0.007 & -0.010 & 0.009 & 0.001 & $0.130 * * *$ \\
\hline & $(0.013)$ & $(0.015)$ & $(0.011)$ & $(0.010)$ & $(0.013)$ & $(0.009)$ & $(0.018)$ & $(0.001)$ \\
\hline Personal & & & & & & & & \\
\hline $\begin{array}{l}\text { Income Tax } x \\
\text { Dev }\end{array}$ & $0.025^{*}$ & $0.067 * * *$ & 0.009 & 0.016 & -0.004 & -0.006 & 0.014 & 0.001 \\
\hline & $(0.015)$ & $(0.016)$ & $(0.014)$ & $(0.014)$ & $(0.015)$ & $(0.010)$ & $(0.020)$ & $(0.001)$ \\
\hline Internet & & & & & & & & \\
\hline $\begin{array}{l}\text { Access } \\
\text { (Internet) }\end{array}$ & $0.007^{* * *}$ & 0.001 & $0.008 * * *$ & $0.010 * * *$ & $0.011 * * *$ & $0.009 * * *$ & $0.024 * * *$ & 0.001 \\
\hline & (0.003) & $(0.003)$ & $(0.002)$ & $(0.002)$ & $(0.003)$ & $(0.002)$ & (0.004) & (0.001) \\
\hline $\begin{array}{l}\text { Internet } \\
\text { Dev }\end{array}$ & -0.009 & $-0.019 * * *$ & $0.018 * * *$ & -0.003 & -0.004 & -0.008 & -0.006 & 0.001 \\
\hline & $(0.007)$ & $(0.007)$ & $(0.006)$ & $(0.007)$ & $(0.008)$ & $(0.007)$ & $(0.009)$ & (0.001) \\
\hline $\begin{array}{l}\text { ICT Goods } \\
\text { Export }\end{array}$ & $0.262 * * *$ & $0.053^{* * *}$ & $0.341 * * *$ & $0.297^{* * *}$ & $0.225^{* * *}$ & $0.160 * * *$ & $0.164 * * *$ & $0.072 * * *$ \\
\hline & $(0.019)$ & $(0.018)$ & $(0.017)$ & $(0.015)$ & $(0.021)$ & $(0.021)$ & $(0.028)$ & $(0.001)$ \\
\hline $\begin{array}{l}\text { ICT Goods } \\
\text { Export } \times \text { Dev }\end{array}$ & $-0.198 * * *$ & $-0.043^{* *}$ & $-0.185 * * *$ & $-0.207 * * *$ & $-0.153^{* * *}$ & $-0.076 * * *$ & -0.033 & 0.001 \\
\hline & $(0.021)$ & $(0.017)$ & $(0.021)$ & $(0.018)$ & $(0.022)$ & $(0.017)$ & $(0.029)$ & $(0.001)$ \\
\hline $\begin{array}{l}\text { ICT Service } \\
\text { Export }\end{array}$ & $-0.096 * * *$ & $-0.115 * * *$ & $-0.043^{* *}$ & $-0.062 * * *$ & $-0.091 * * *$ & $-0.037^{*}$ & $-0.210 * * *$ & $0.005^{* * *}$ \\
\hline
\end{tabular}




\begin{tabular}{|c|c|c|c|c|c|c|c|c|}
\hline & $(0.024)$ & $(0.021)$ & $(0.020)$ & $(0.017)$ & $(0.028)$ & $(0.020)$ & $(0.036)$ & (0.001) \\
\hline $\begin{array}{l}\text { ICT Service } \\
\text { Export } \times \text { Dev }\end{array}$ & $\begin{array}{c}0.115^{* * *} \\
(0.026)\end{array}$ & $\begin{array}{r}0.125 * * * \\
(0.024)\end{array}$ & $\begin{array}{r}0.046 * * \\
(0.023)\end{array}$ & $\begin{array}{c}0.048 * * \\
(0.020)\end{array}$ & $\begin{array}{r}0.118 * * * \\
(0.030)\end{array}$ & $\begin{array}{r}0.080 * * * \\
(0.021)\end{array}$ & $\begin{array}{r}0.305^{* * *} \\
(0.039)\end{array}$ & $\begin{array}{r}0.001 \\
(0.001)\end{array}$ \\
\hline $\begin{array}{l}\text { Average } \\
\text { Import Tariff }\end{array}$ & $\begin{array}{l}-0.024 \\
(0.015)\end{array}$ & $\begin{array}{r}-0.118 * * * \\
(0.026)\end{array}$ & $\begin{array}{l}-0.014 \\
(0.011)\end{array}$ & $\begin{array}{r}-0.007 \\
(0.009)\end{array}$ & $\begin{array}{r}-0.017 \\
(0.019)\end{array}$ & $\begin{array}{l}-0.046 * \\
(0.026)\end{array}$ & $\begin{array}{r}-0.117^{* * *} \\
(0.028)\end{array}$ & $\begin{array}{r}-0.067 * * * \\
(0.001)\end{array}$ \\
\hline Average & & & & & & & & \\
\hline $\begin{array}{l}\text { Import Tariff } \\
\times \text { Dev }\end{array}$ & $\begin{array}{r}-0.034 * * \\
(0.016)\end{array}$ & $\begin{array}{r}0.103 * * * \\
(0.028)\end{array}$ & $\begin{array}{r}-0.076 * * * \\
(0.017)\end{array}$ & $\begin{array}{r}-0.041 * * * \\
(0.011)\end{array}$ & $\begin{array}{r}-0.055^{* * *} \\
(0.020)\end{array}$ & $\begin{array}{r}0.014 \\
(0.027)\end{array}$ & $\begin{array}{l}0.059 * * \\
(0.029)\end{array}$ & $\begin{array}{r}0.001 \\
(0.001)\end{array}$ \\
\hline Dev & $\begin{array}{r}2.355^{* * *} \\
(0.485)\end{array}$ & $\begin{array}{r}1.413^{* * *} \\
(0.423)\end{array}$ & $\begin{array}{r}3.357^{* * *} \\
(0.533)\end{array}$ & $\begin{array}{r}4.168 * * * \\
(0.445)\end{array}$ & $\begin{array}{l}1.022 * \\
(0.533)\end{array}$ & $\begin{array}{r}1.332 * * * \\
(0.432)\end{array}$ & $\begin{array}{r}-0.103 \\
(0.646)\end{array}$ & $\begin{array}{r}0.001 \\
(0.001)\end{array}$ \\
\hline T95 & $\begin{array}{r}0.467^{* * *} \\
(0.072)\end{array}$ & $\begin{array}{r}0.345^{* * *} \\
(0.063)\end{array}$ & $\begin{array}{r}0.267^{* * *} \\
(0.071)\end{array}$ & $\begin{array}{r}-0.078 \\
(0.061)\end{array}$ & $\begin{array}{r}0.804^{* * *} \\
(0.082)\end{array}$ & $\begin{array}{l}0.138^{* *} \\
(0.061)\end{array}$ & $\begin{array}{r}0.738 * * * \\
(0.116)\end{array}$ & $\begin{array}{r}0.568 * * * \\
(0.001)\end{array}$ \\
\hline $\begin{array}{l}\text { Observation } \\
\mathrm{s}\end{array}$ & 239 & 195 & 222 & 241 & 216 & 218 & 203 & 151 \\
\hline $\begin{array}{l}\text { Wald Chi } \\
\text { Squared }\end{array}$ & 9023.58 & 32084.12 & 8016.40 & 9115.27 & 8325.91 & $17,262.84$ & $7,894.27$ & $2.76 \mathrm{E}+15$ \\
\hline $\begin{array}{l}\text { Prob > Chi } \\
\text { Squared }\end{array}$ & 0.000 & 0.000 & 0.000 & 0.000 & 0.000 & 0.000 & 0.000 & 0.000 \\
\hline $\begin{array}{l}\text { Log } \\
\text { Likelihood }\end{array}$ & -126.662 & $-75 \cdot 318$ & -103.207 & -108.546 & -108.126 & -84.490 & -141.952 & -441.610 \\
\hline
\end{tabular}

Note: Robust standard errors are given in parentheses and statistical significance of the estimated coefficients are given at the conventional $10 \%(*), 5 \%(* *)$, and $1 \%(* * *)$ levels. Internet = percent of people with access to internet. The binary variable Dev takes on a value of 1 for developing countries and 0 otherwise. Binary variable T95 takes on a value of 1for years $>=1995$ or o otherwise. Trade openness is measured as ratio of value of value of export plus import to GDP. In the Generalized Least Squared model, I control for auto-correlation and Heteroskedasticity. ICT implies Information and Communication Technologies.

The estimated coefficients for ethnic diversity for high income countries, as shown in Table 6, are mostly positive across all three variant specifications (except in RE determinant model), but it was statistically significant only in the determinant model for the random effect specification. Sign and magnitude of the estimated coefficient of the interaction variable (ethnic diversity $\times$ developing countries) suggest that positive influence of ethnic diversity is larger for developing countries than for high income or developed countries. According to GLS results for eight manufacturing industries as shown in Table 8, influence of ethnic diversity on specific industries also are mostly positive and significant except for plastic industry for which it was negative and not significant. The coefficients for the interaction term (diversity $x$ developing) suggest that ethnic diversity largely played out as a negative influence on innovation activities in developing countries. The negative influence of diversity in developing countries' patent yielding innovation activities was particularly large in chemical, plastic, pharmaceutical, and plastic industries. However, it was positive (although not significant) for textile industry for both high income and developing countries. Table 7 shows mostly similar signs of estimated coefficients as seen in Table 6 and Table 8. Therefore, diversity implies to be a positive factor of innovation activities.

The Estimated coefficients of electricity as in Table 6 and Table 7 are largely positive and significant in both globalization model and determinant model across RE and GLS specifications (except in FE globalization model). Signs and magnitude of coefficient of the interaction variable (power $\times$ developing) suggest that influence of power in patented innovation activities is positive and significant, but slightly smaller in magnitude for developing countries relative to high income countries. GLS regression results as in Table 8 suggest that electricity usage is generally a positive factor for patented innovation activities in seven industries in developing countries of which the impact of the variable for petroleum, machinery, plastic, and computer are significantly positive. For developing countries, for four industries (petroleum, machinery, plastic, and computer) the impact of per capita power consumption was positive and 
significant, for textile the estimated coefficient was positive but not statistically significant and for chemical, electric, and pharmaceutical industries, the estimated coefficients were negative.

In Table 6, Tertiary education seemed to have significant positive influence on patented innovation in the FE globalization model and positive but non-significant influence on patented innovation for RE and FE determinant models, and GLS globalization model for high income countries. The interaction term coefficients suggested some ambiguous results. For GLS determinant model for developing countries the impact of tertiary education on patented innovation was positive and statistically significant and for RE determinant model, and FE determinant and GLS models the impact was positive but not significant. Table 7 results imply that tertiary education is not a good determinant of number of patent application submission as for most of the variant models the estimated coefficients are not positive. However, results presented in Table 8 suggest that tertiary education has positive and significant impact on patented innovation in plastic industry, petroleum and computer industries.

As shown in Table 6, the estimated coefficient of R\&D variable turned out to be positive and significant in two but all models and specifications (for RE-globalization model and GLS-globalization model the estimated coefficients were positive but not statistically significant). Similar results are found for Table 8 where R\&D expenditure is found to be positive determinant of patent count for most of the eight manufacturing industries (except for machinery industry). For Table 7, the R\&D variable's estimated coefficient was positive for GLS model only. The estimated coefficient of corporate income tax (CIT) variable is generally positive and significant in Table 6 regression specifications (except for FE globalization model in which it was negative). However, for Table 7 and Table 8 this variable's impact was ambiguous.

Influence of personal income tax (PIT) on innovation is ambiguous across Table 6, Table 7, and Table 8. However, in Table 6, PIT's influence on patented innovation in both the cohort countries is mostly positive when industry specific impacts were mixed in Table 8 (for chemical and petroleum industries, impact of personal income tax on number of granted patent was positive and significant at conventional levels.

Internet access has a significant positive impact on innovation across measures, sectors, and country cohorts in the study. According to the estimated coefficients of the interaction variable for developing countries, internet access is a positive and statistically significant influence across the RE, FE, and GLS models in Table 6 through Table 8. As shown in Table 7, across country cohorts impact of internet is positive and significant in six industries (chemical, electric, machinery, pharmaceutical, plastic, and computer industries) and positive but not statistically significant for petroleum and textile industries.

According to Table 6, influence of ICT-goods export on patented innovation is positive across all the specifications but is statistically significant for RE and GLS specifications. For developing countries, the impact of this variable is surprisingly negative although this result seems to be an anomaly when we review the industry specific regression results in Table 8 for this variable where this variable's estimated coefficient is positive and significant for all eight manufacturing sectors.

In Table 8, impact of ICT-goods export variable is positive and statistically significant for high income countries across all industries. For developing countries, the estimated coefficients of the interaction variable suggest that the impact of ICT-goods export is positive and statistically significant for six industries (chemical, petroleum, electric, machinery, pharmaceutical, and, plastic). However, the positive impact of ICT export variable on patented innovation is slightly smaller in magnitude for developing countries than for high income countries. Impact of ICT-service export variable is found to be negative and significant for high income countries. On the other hand, the interaction variable's estimated coefficients suggest that impact of ICT-service export on patented innovation is positive and significant for developing countries. It is plausible to contend that ICT-service export contributes to international diffusion of productive knowledge. Perhaps because of this reason ICT-service export variable is 
influencing developing countries' patented innovation positively and high-income countries' patented innovation negatively.

As shown in Table 8, impact of ICT-service export is negative and significant across all eight manufacturing industries for high income countries. In the estimated coefficients of the interaction terms for ICT-services export variable, we see that seven out of eight industries in developing countries the impact of ICT-service export is positive and significant. For textile industry, it is positive but not significant.

As shown in Table 6, estimated coefficient of average import tariff rate is negative across all three specifications (RE, FE, and GLS) although it is statistically significant only in GLS globalization model. For developing countries impact of import tariff rate is ambiguous and not statistically significant. Estimated coefficients for trade openness variable as reported in Table 6, Table 7, and Table 8 suggest that it is an ambiguous factor of innovation activities measured by granted patent or patent applications submitted. However, when trade openness is considered only for developing country cohort, it showed positive influence on innovation across regression models. It appears that trade openness served as a stronger stimulant of innovation activities for developing countries' but not so for the cohort of developed or high-income countries.

Table 8 also shows for individual eight industries in high income countries, the impact of tariff rate is negative and significant for six industries. For developing countries, tariff rate is negative and significant for all eight industries out of which four are significant (petroleum, plastic, computer, and textile). Negative relationship between import duty and patented innovation imply that higher rate discourages international trade, and, thereby, international knowledge spillover prospects. As international flow of knowledge embodied in traded goods and services is hindered due to tariff barriers, innovation activities may suffer resulting in drop in number of patents granted. The binary variables T95 and Developing countries are mostly statistically significant for both high income countries and developing countries.

\section{Conclusion}

This paper measures innovation by count of patents granted by USPTO and counts of patent applications received by incumbent countries. Measures of innovation include patent count, patent application intensity, R\&D expenditure, research output publication, total factor productivity etc. As in Morck and Yeung (2001), difference between innovation count and patent count is that a patent helps us in separating 'important innovation' (for which patents are granted) from 'unimportant innovation' (those whose patents are denied or yet to be granted). Thus, patent represents a subset of all innovation activities and using patent as the only testament of innovation is a judgment call. Patent count data used in this study are all issued by U.S.P.T.O. Arguably, during the cold war era some countries were not as enthusiastic in patenting their innovations in the U.S. Because of political divisions, until the beginning of 1990 s not many former Soviet countries (countries that are now known as Commonwealth of Independent States) would apply for U.S. patent. Therefore, US. Granted patent count and patent application count both needs to be taken into consideration as measures of innovative activities and doing so would serve as a robustness check of measure of innovation activities. Also, inclusion of more countries in each cohort may have increased the robustness of the results.

Innovation is becoming increasingly important in the $21^{\text {st }}$ century when 'creative destruction' is happening at a rate never seen before. To stay competitive in the international market both high income countries and developing countries need to promote positive factors that increase innovation activities. In this study, I test the hypotheses that relative effectiveness of various aggregate variables as predictors of innovation activities for two cohorts: developed (high income) countries, and developing countries, and that forces of globalization may influence the innovation activities differentially across development echelons. Statistical results obtained largely support the hypotheses although in few instances results showed some aberration from intuition. Ethnic diversity is found to be an innovation promoting factor regardless of the state of development of the economy. The regressor 'ICT-service export', when 
interacted with developing countries' dummy variable, boosted innovation activities, whereas regressor 'ICT-goods export' when interacted with developing countries' dummy variable, became a negative influence on innovation activity. From the obtained regression results, it appears that policy planners interested in boosting innovation activities should also advocated for ethnic diversity. Also, policy planners from developing countries should focus more on ICT-service export relative to ICT goods export to accelerate their innovation activities. Future research in this area should include more countries in each cohort type allowing for longer time horizon to find more statistically robust results as microeconomic and macroeconomic data series from both developed and developing countries continue to become available.

\section{References}

Almeida, R. K., \& Fernandes, A. M. (2007). Openness and Technological Innovations in Developing Countries: Evidence from Firm-Level Surveys (No. 2907): IZA

Audretsch, D. B., \& Feldman, M. P. (1996). R\&D spillovers and the geography of innovation and production. The American economic review, 86(3), 630-640.

Bluestone, B. and A. Clayton-Matthews (2013). Life Sciences Innovation as a Catalyst for Economic Development: The Role of the Massachusetts Life Sciences Center. The Kitty and Michael Dukakis Center for Urban and Regional Policy, Boston, Massachusetts:1-60.

Bordo, M. D., Taylor, A. M., \& Williamson, J. G. (2003). Globalization in Historical Perspectives. Paper presented at the Globalization in Historical Perspectives.

Chen, L., \& De Lombaerde, P. (2014). Testing the relationships between globalization, regionalization and the regional hubness of the BRICs. Journal of Policy Modeling, 36, S111-S131.

Cohen, S. S., \& Zysman, J. (1988). Manufacturing Innovation and American Industrial Competitiveness. Science, 239(4844), 1110-1115.

Colecchia, A., \& Schreyer, P. (2002). ICT investment and economic growth in the 1990s: is the United States a unique case? a comparative study of nine OECD countries. Review of Economic Dynamics, 5(2), 408-442.

Council on Competitiveness (2005). Innovate America: National Innovation Initiative Summit and Report (pp. 1-93).

Deloitte LLP (2016). Global manufacturing competitiveness report, Council on Competitiveness, pp. 1-12.

Diez, F. J., \& Gopinath, G. (2014). The competitiveness of U.S. manufacturing. Boston, MA: Federal Reserve Bank of Boston.

d'Agostino, G. and M. Scarlato (2015). "Innovation, Socio-institutional Conditions and Economic Growth in the Italian Regions." Regional Studies 49(9): 1514-1534.

Engel, J. S. (2015). Global Clusters of Innovation: Lessons from Silicon Valley. California Management Review, 57(2): 36-65.

Falk, M. (2004). What Determines Patents Per Capita in OECD Countries? Vienna Austrian Institute of Economic Research.

Frenkel, A., \& Maital, S. (2014). Mapping National Innovation Ecosystems: Foundations for Policy Consensus: Edward Elgar Publishing.

Gobble, M. M. (2014). Charting the innovation ecosystem. Research-Technology Management, 57(4), 5559.

Gordonichenko, Y., Svejnar, J., \& Terrell, K. (2010). Globalization and Innovation in Emerging Markets. American Economic Journal: Macroeconomics, 2(2), 194-226.

Gorodnichenko, Yuriy, Jan Svejnar, and Katherine Terrell. (2008). Globalization and Innovation in Emerging Markets. NBER Working Paper No. 14481.

Grossman, G. M., \& Helpman, E. (1993). Innovation and growth in the global economy: MIT press.

Green, W. (2008). Econometric Analysis (6th ed.). Upper Saddle River, N.J.: Prentice Hall.

Jackson, D. J. (2011). What is an innovation ecosystem? National Science Foundation, 1.

Jaffe, A. B., Trajtenberg, M., \& Henderson, R. (1993). Geographic localization of knowledge spillovers as evidenced by patent citations. the Quarterly journal of Economics, 108(3), 577-598.

Jalava, J., \& Pohjola, M. (2002). Economic growth in the new economy: Evidence from advanced economies. Information Economics and policy, 14(2), 189-210. 
Khan, A. M., \& Roy, P. A. (2011). Globalization and the Determinants of Innovation in BRICS versus OECD Economies: A Macroeconomic Study. Journal of Emerging Knowledge in Emerging Markets, 3, 29-45.

Kirimaya, N. (2012). Trade and Innovation Synthesis Report. OECD Trade Policy Papers no. 135. OECD

Lee, C. (2004). The Determinants of Innovation in the Malaysian Manufacturing Sector: An Econometric Analysis at the Firm Level. ASEAN Economic Bulletin, 21(3), 319-329.

Love, J. H., \& Roper, S. (1999). The determinants of innovation: R \& D, technology transfer and networking effects. Review of Industrial Organization, 15(1), 43-64.

Mankiw, N. G., Romer, D., \& Weil, D. N. (1992). A contribution to the empirics of economic growth. the Quarterly journal of Economics, 107(2), 407-437.

Mas, M., \& Quesada, J. (2005). ICT and Economic Growth.

Morck, R., \& Yeung, B. (2001). The Economic Determinants of Innovation (No. 25): Industry Canada

Naude, W., Szirmai, A., \& Goedhuys, M. (2011). Innovation and entrepreneurship in developing countries: United Nation's University.

NASSCOM. (2011). The IT-BOP Sector in India: Strategic Review

Nathan, M., \& Lee, N. (2013). Cultural Diversity, Innovation, and Entrepreneurship: Firm-level Evidence from London. Economic Geography, 89(4), 367-394.

Neill, J. O. (2007). BRICS and Beyond. New York: Goldman Sachs.

OECD (2007). Innovation and growth rationale for an innovation strategy, Paris: 1-29. (full text download link: http://www.oecd.org/sti/inno/39374789.pdf)

OECD. (2012). Innovation for Development.

OECD Trade database (2017). (data retrieved from https://stats.oecd.org/Index.aspx?DataSetCode= MEI_TRD\#)

Onodera, O. (2008). Trade and Innovation Project: A Synthesis Paper. Organization of Economic Cooperation and Development.

Ostergaard, C. R., \& Timmermans, B. (2011). Does a different view create something new? The effect of employee diversity on innovation. Research Policy, 40(3), 500-509.

Ozgen, C., Nijkamp, P., \& Poot, J. (2011). The impact of cultural diversity on innovation: evidence from Dutch firm-level data.

Paris: OECD. (full text download: https://www.oecd.org/cfe/tourism/34267902.pdf)

Parrotta, P., Pozzoli, D., \& Pytlikova, M. (2014). The nexus between labor diversity and firm's innovation. Journal of Population Economics, 27(2), 303-364.

Quatraro, F. (2010). Knowledge coherence, variety and economic growth: manufacturing evidence from Italian regions. Research Policy, 39(10), 1289-1302.

Rogers, M. (2004). Networks, Firm Size and Innovation. Small Business Economics, 22, pp. 141-153.

Romer, P. M. (1994). The origins of endogenous growth. The journal of economic perspectives, 8(1), 3-22.

Romer, P. M. (1990). Endogenous technological change. Journal of political Economy, 98(5, Part 2), S71S102.

Romer, P. M. (1986). Increasing returns and long-run growth. Journal of political Economy, 94(5), 10021037.

Rosenberg, N. (2004). Innovation and economic growth. Paper presented at the Conference on Innovation and Growth in Tourism, Lugano, Switzerland.

Sala-i-Martin, X. (2002). 15 Years of New Growth Economics: What Have We Learnt? Department of Economics Discussion Paper No. 0103-47. Columbia University.

Schumpeter, J. A. (1942). Capitalism, Socialism and Democracy. New York: Harper.

Solow, R. M. (1957). Technical change and the aggregate production function. The review of Economics and Statistics, 312-320.

Solow, R. M. (1956). A contribution to the theory of economic growth. the Quarterly journal of Economics, 70(1), 65-94.

Statistics Canada report on Manufacturing. Data retrieved from the weblink: http://www.statcan.gc.ca/pub/11-402-x/2011000/chap/man-fab/man-fab-eng.htm

ŞTefan, G. and O. Coca (2015). "Empirical evidences regarding the role of innovation in economic growth." Agronomy Series of Scientific Research / Lucrari Stiintifice Seria Agronomie 58(1): 195-198

Subrahmanya, M. H. B. (2011). Technological Innovations and Firm Performance of Manufacturing SMEs: Determinants and Outcomes. ASCl Journal of Management, 41(1), 
Ulku, H. (2007). R\&D, Innovation, and Growth: Evidence from Four Manufacturing Sectors in OECD Countries. Oxford Economic Papers, 59(3), new series, 513-535. Retrieved from http://www.jstor.org.ezproxy.claflin.edu/stable/4500121

United States Census Bureau. County Business Pattern online database (cited data retrieved from following weblink: https://www.census.gov/data/datasets/1986/econ/cbp/1986-cpb.html).

United States International Trade Commission online database (cited data retrieved from following weblink: https://www.usitc.gov/research_and_analysis/trade_shifts_2014/us_trade_by_industry_ sector.htm).

Uppenberg, K. (2011). Innovation and Economic Growth. 14: 10-35.

Wu, Y. (2010). Indigenous innovation for sustainable growth. China: The Next Twenty Years of Reform and Development, ANU Press. 2010:341-362.

\section{Appendix section}

Table 1 (appendix section): correlations of total patents count and main regressors

\begin{tabular}{|c|c|c|c|c|c|c|c|c|c|c|}
\hline & $\begin{array}{r}\text { All } \\
\text { patent }\end{array}$ & $\begin{array}{r}\text { Internet } \\
\text { access }\end{array}$ & diversity & $\begin{array}{c}\text { Use of } \\
\text { electricity e }\end{array}$ & $\begin{array}{l}\text { Tertiary } \\
\text { ducation }\end{array}$ & $\begin{array}{r}\text { R\&D expen- } \\
\text { diture \% of } \\
G D P\end{array}$ & $\begin{array}{r}\text { Open- } \\
\text { ness }\end{array}$ & $\begin{array}{l}\text { ICT- } \\
\text { goods } \\
\text { export }\end{array}$ & $\begin{array}{r}\text { ICT- } \\
\text { service } \\
\text { export }\end{array}$ & $\begin{array}{r}\text { Average } \\
\text { tariff } \\
\text { rate }\end{array}$ \\
\hline All patent & 1.000 & & & & & & & & & \\
\hline $\begin{array}{l}\text { Internet } \\
\text { access }\end{array}$ & 0.335 & 1.000 & & & & & & & & \\
\hline diversity & -0.063 & 0.213 & 1.000 & & & & & & & \\
\hline $\begin{array}{l}\text { Use of } \\
\text { electricity }\end{array}$ & 0.510 & 0.449 & 0.355 & 1.000 & & & & & & \\
\hline $\begin{array}{l}\text { Tertiary } \\
\text { Education } \\
\text { R\&D }\end{array}$ & 0.432 & 0.397 & -0.037 & 0.529 & 1.000 & & & & & \\
\hline $\begin{array}{l}\text { expenditur } \\
\text { e \% of GDP }\end{array}$ & 0.627 & 0.425 & 0.119 & 0.781 & 0.601 & 1.000 & & & & \\
\hline openness & -0.233 & 0.194 & 0.225 & -0.063 & -0.075 & -0.286 & 1.000 & & & \\
\hline $\begin{array}{l}\text { ICT-goods } \\
\text { export }\end{array}$ & 0.121 & 0.065 & 0.091 & -0.195 & -0.089 & -0.126 & 0.695 & 1.000 & & \\
\hline $\begin{array}{l}\text { ICT-service } \\
\text { export }\end{array}$ & -0.087 & -0.104 & 0.082 & -0.268 & -0.187 & -0.145 & -0.156 & -0.182 & 1.000 & \\
\hline $\begin{array}{l}\text { Average } \\
\text { tariff } \\
\text { rate }\end{array}$ & -0.214 & -0.450 & -0.106 & -0.462 & -0.442 & -0.289 & -0.283 & 0.006 & 0.516 & 1.000 \\
\hline
\end{tabular}

Table 2: (appendix section) correlation of eight industry patent count variables

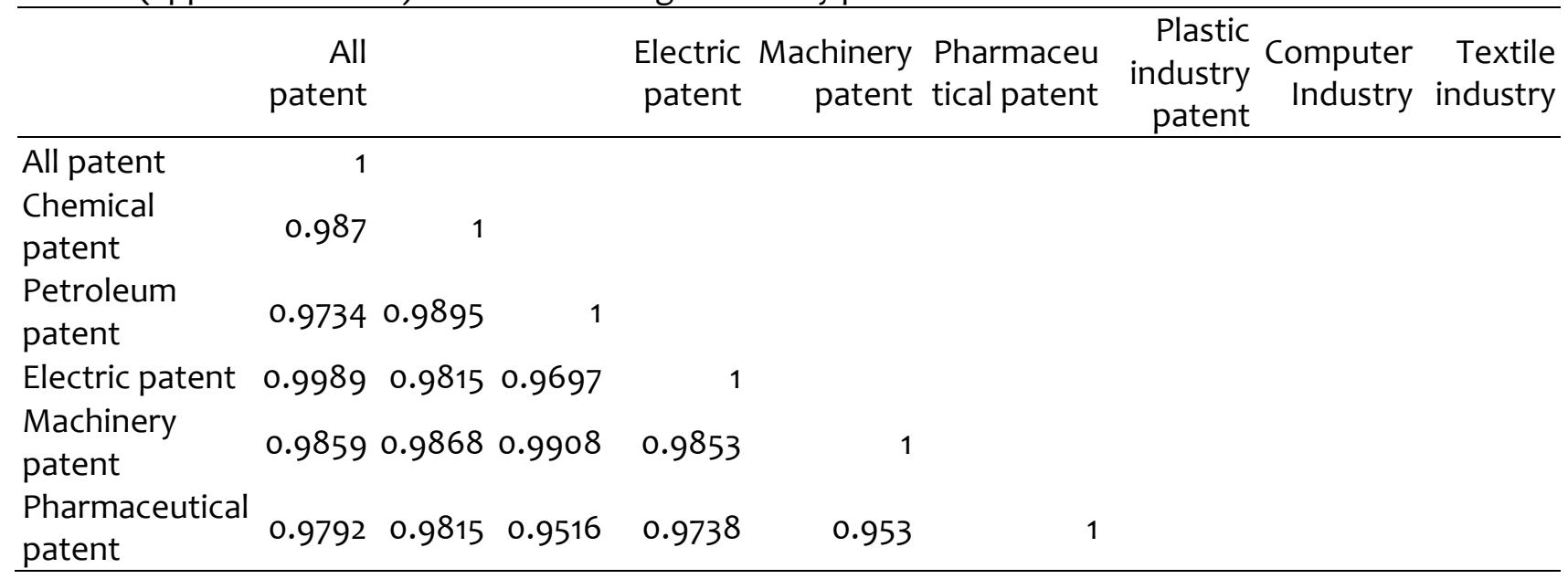




\begin{tabular}{lrllllllll}
\hline $\begin{array}{l}\text { Plastic industry } \\
\text { patent }\end{array}$ & 0.9656 & 0.9874 & 0.9981 & 0.9604 & 0.9874 & 0.9451 & 1 & & \\
$\begin{array}{l}\text { Computer } \\
\text { Industry }\end{array}$ & 0.9306 & 0.8728 & 0.8238 & 0.9339 & 0.865 & 0.9174 & 0.8049 & 1 & \\
Textile industry & 0.9791 & 0.9942 & 0.9933 & 0.9733 & 0.9857 & 0.9689 & 0.9934 & 0.8477 & 1 \\
\hline
\end{tabular}

